\title{
Benthic foraminifera as tracers of brine production in the Storfjorden "sea ice factory"
}

\author{
Eleonora Fossile ${ }^{1}$, Maria Pia Nardelli ${ }^{1}$, Arbia Jouini $^{1}$, Bruno Lansard ${ }^{2}$, Antonio Pusceddu ${ }^{3}$, Davide Moccia $^{3}$, \\ Elisabeth Michel ${ }^{2}$, Olivier Péron ${ }^{4}$, Hélène Howa ${ }^{1}$, and Meryem Mojtahid ${ }^{1}$ \\ ${ }^{1}$ LPG-BIAF UMR-CNRS 6112, UNIV Angers, CNRS, UFR Sciences, 2 bd Lavoisier 49045, Angers CEDEX 01, France \\ ${ }^{2}$ LSCE, UMR 8212, IPSL-CEA-CNRS-UVSQ-Université Paris Saclay, 91198 Gif-sur-Yvette, France \\ ${ }^{3}$ Department of Life and Environmental Sciences, University of Cagliari, 09126 Cagliari, Italy \\ ${ }^{4}$ SUBATECH, UMR 6457, CNRS-Université de Nantes, 4 rue A. Kastler, 44307 Nantes, France
}

Correspondence: Eleonora Fossile (eleonora.fossile@etud.univ-angers.fr)

Received: 4 October 2019 - Discussion started: 15 November 2019

Revised: 10 February 2020 - Accepted: 2 March 2020 - Published: 9 April 2020

\begin{abstract}
The rapid response of benthic foraminifera to environmental factors (e.g. organic matter quality and quantity, salinity, $\mathrm{pH}$ ) and their high fossilisation potential make them promising bio-indicators for the intensity and recurrence of brine formation in Arctic seas. Such an approach, however, requires a thorough knowledge of their modern ecology in such extreme settings. To this aim, seven stations along a north-south transect across the Storfjorden (Svalbard archipelago) have been sampled using an interface multicorer. This fjord is an area of intense sea ice formation characterised by the production of brine-enriched shelf waters (BSW) as a result of a recurrent latent-heat polynya. Living (rose bengal-stained) foraminiferal assemblages were analysed together with geochemical and sedimentological parameters in the top $5 \mathrm{~cm}$ of the sediment. Three major biozones were distinguished. (i) The "inner fjord" zone, dominated by typical glacier proximal calcareous species, which opportunistically respond to fresh organic matter inputs. (ii) The "deep basins and sill" zone, characterised by glacier distal agglutinated fauna; these are either dominant because of the mostly refractory nature of organic matter and/or the brine persistence that hampers the growth of calcareous species and/or causes their dissolution. (iii) The "outer fjord" zone, characterised by typical North Atlantic species due to the intrusion of the North Atlantic water in the Storfjordrenna. The stressful conditions present in the deep basins and sill (i.e. acidic waters and low food quality) result in a high agglutinated / calcareous ratio (A/C). This supports
\end{abstract}

the potential use of the $\mathrm{A} / \mathrm{C}$ ratio as a proxy for brine persistence and overflow in Storfjorden.

\section{Introduction}

The polar regions are particularly sensitive to climate change, as evidenced from the several dramatic alterations in recent decades (Peings, 2018). For instance, Arctic surface temperatures have increased at twice the global rate (i.e. Arctic amplification; Holland and Bitz, 2003; Dai et al., 2019), while sea ice cover has been steadily decreasing over recent decades both in extent and volume (IPCC, 2013; Labe et al., 2018). With less ice present, the ocean surface absorbs considerably more sunlight energy. This leads to further warming of the atmosphere and the ocean, therefore enhancing sea ice melting, which, in turn, affects marine and continental ecosystems (Perovich and Richter-Menge, 2009).

A recent review study compiling several high-resolution terrestrial proxies show that the modern decline in Arctic sea ice is unprecedented compared to at least the last few thousand years and is unexplainable by known natural variability (e.g. Kinnard et al., 2011). To better understand how and how much natural and anthropogenic forcing factors control sea ice dynamics, there is a need for more high-resolution marine time series covering the historical period (i.e. hundreds of years) and for robust biological proxies in key areas from the circum-Arctic. Storfjorden, a semi-enclosed bay located in the Svalbard archipelago (Fig. 1a), is one of the Arctic re- 
gions particularly suitable for studying first-year sea ice dynamics. Indeed, Skogseth et al. (2004) defined Storfjorden as an "ice factory" because of the presence of a recurrent coastal polynya that contributes to about $5 \%-10 \%$ to the total brine waters produced on Arctic shelves (Smedsrud et al., 2006). Brine are salty and $\mathrm{CO}_{2}$-rich waters (i.e. low $\left.\mathrm{pH}\right)(\mathrm{Rysgaard}$ et al., 2011) that are produced when sea ice forms in inner fjords, and for this reason they can be used as proxies for sea ice production. Because of their high density, they cascade after mixing with shelf waters (Skogseth et al., 2005a) and ventilate the deep sea (Rumohr et al., 2001). During cascading, brine may cause sedimentary disturbance as they can release downslope turbidity flows (Rumohr et al., 2001) and, in the meantime, export particulate and dissolved inorganic and organic carbon from the productive surface waters down to the seafloor (Anderson et al., 2004). The brine's contribution to maintaining the halocline of the Arctic Ocean (Aagaard et al., 1985; Cavalieri and Martin, 1994) and its influence on the ocean circulation further underline the need to study brine evolution in recent times in relation to global warming. In fact, the current Arctic amplification will determine a decrease in the production of sea ice in several polynyas from the Arctic region (Tamura and Ohshima, 2011) and, in the future scenario of an ice-free Arctic Ocean during summer (IPCC, 2013), sea ice factories will gradually disappear. However, these predictions are largely based on direct observations on a short timescale (i.e. satellite data since 1979), which only opens a narrow window on the natural variability of sea ice dynamics. The scientific community is now focusing on longer time series to place the recent trends in a longer-term perspective (i.e. multi-centennial timescale) (Nicolle et al., 2018) and validate these scenarios.

Benthic foraminifera are among the most abundant protists living in marine ecosystems, from brackish waters to abyssal plains (e.g. Murray, 2006). Due to their short life cycle, high diversity and specific ecological requirements, they respond quickly to the physicochemical environmental conditions (e.g. organic inputs, oxygenation, $\mathrm{pH}$ ) by increasing their density (e.g. Kitazato et al., 2000), changing the faunal composition or modifying their microhabitat (Jorissen et al., 1995; Ohga and Kitazato, 1997). Therefore, benthic foraminifera are potentially good proxies for brine waters that bathe the deep-sea Arctic environments directly and for sea ice production indirectly. The existing benthic foraminiferal-based studies in Storfjorden used fossil fauna to interpret late Quaternary paleoenvironmental changes (Rasmussen and Thomsen, 2009, 2014, 2015). Although highlighting major difficulties in the interpretation of most of these paleo-records without modern proxy calibrations, those studies further suggested the ratio of agglutinated to calcareous benthic foraminifera as a potential proxy for brine changes. Living foraminiferal distributions have been, however, studied in several Svalbard fjords, in particular in relation to the distance from tidewater glaciers and the associated sedimentary supply (Hansen and Knud- sen, 1995; Korsun et al., 1995; Hald and Korsun, 1997; Korsun and Hald, 2000; Sabbatini et al., 2007; Ivanova et al., 2008; Forwick et al., 2010; Zajączkowski et al., 2010; Łącka and Zajączkowski, 2016; Jernas et al., 2018). To our knowledge, none of these studies targeted the influence of brineenriched shelf waters (BSW).

To develop a robust biological marine proxy of environmental variation based on communities of benthic fossil foraminifera, it is crucial to understand their modern ecology well in this specific environment beforehand. To provide new insights on this issue, here we investigate living (rose bengal-stained) benthic foraminiferal fauna from Storfjorden and their response to various measured environmental variables (e.g. sediment characteristics, organic matter quantity and composition, sediment oxygen and $\mathrm{pH}$ microprofiles) that are further linked with BSW. Furthermore, the interpretation of our results integrates the extended literature of the physical oceanography in this specific semi-enclosed bay (e.g. Haarpaintner et al., 2001a, b, c; Omar et al., 2005; Skogseth et al., 2004, 2005a, b, 2008; Geyer et al., 2009; Jardon et al., 2014).

\section{Oceanographic and environmental settings}

The Svalbard archipelago, located north of the Arctic circle, extends from 74 to $81^{\circ} \mathrm{N}$ and 10 to $35^{\circ} \mathrm{E}$ (Fig. 1a). It is surrounded by the Arctic Ocean to the north, the Barents Sea to the south and east, and the Norwegian and Greenland seas to the west. Storfjorden, the biggest fjord in the Svalbard archipelago, is approximately $190 \mathrm{~km}$ long with a maximum water depth of $\sim 190 \mathrm{~m}$ present in a central deep glacial trough (referred to as deep basins in Fig. 1b). The northern part of Storfjorden (i.e. inner fjord; Fig. 1b) is connected with the northwestern Barents Sea by two sounds (Heleysundet and Freemansundet) through where relatively energetic tidal exchanges occur (McPhee et al., 2013). To the south, a sill $\left(77^{\circ} \mathrm{N}-19^{\circ} \mathrm{E}\right)$ about $120 \mathrm{~m}$ deep separates the inner Storfjorden and the deep basins from the outer Storfjorden trough (Storfjordrenna) (Fig. 1a), a 200-300 m deep glacial paleo-valley that incised the western Barents Sea continental margin during previous sea level low stands (Pedrosa et al., 2011).

The Svalbard archipelago is influenced by two major water masses. Along the eastern and southern margin of Svalbard, cold and relatively low saline Arctic waters flow out from the Barents Sea via the East Spitsbergen Current (ESC) (Fig. 1a). In the eastern Norwegian and Greenland seas, the main stream of Atlantic Water, which is the most important source of heat and salty water into the Arctic Ocean, is carried northwards by the Norwegian Atlantic Current (NAC) (Fig. 1a). North of Norway, the NAC splits into two branches: (i) the Norwegian Current (NC, or Norwegian Coastal Current), which enters the Barents Sea eastward around $70^{\circ} \mathrm{N}$ (not shown in Fig. 1a) along the north- 
(a)

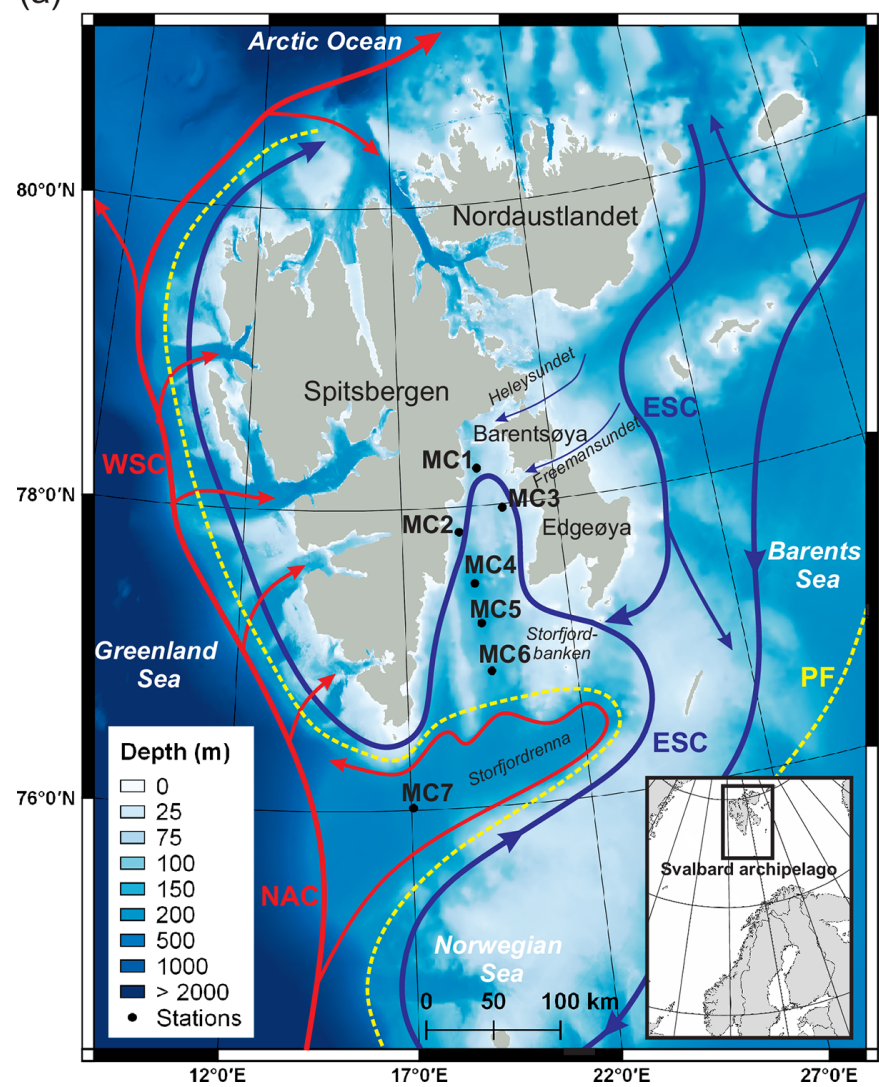

(b)

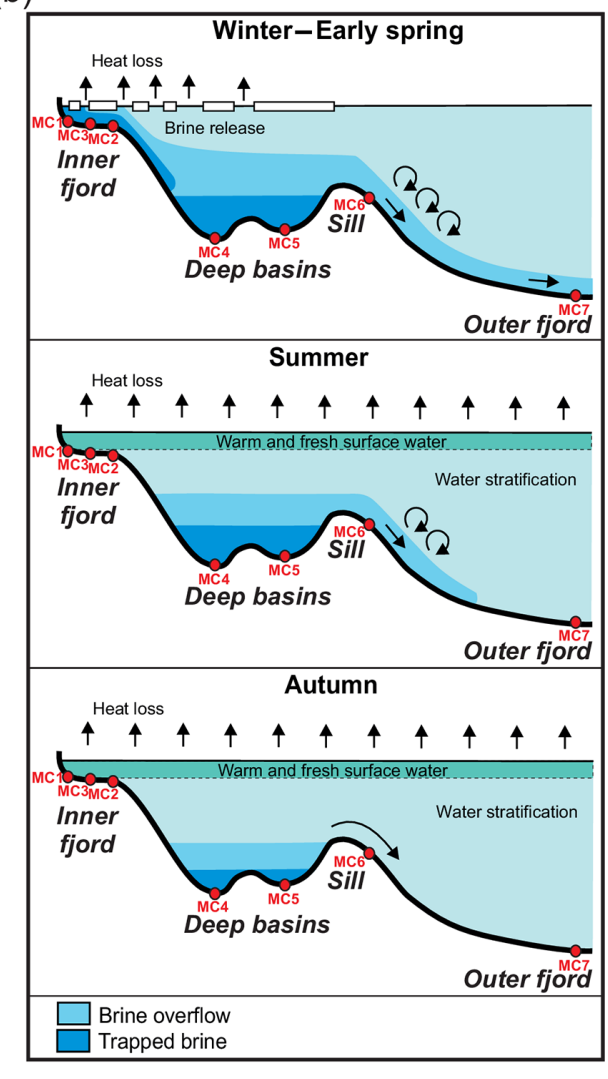

Figure 1. (a) Bathymetric map showing the main current circulations around the Svalbard archipelago (currents from Skogseth et al., 2005b and Misund et al., 2016) and locations of the sampling stations. The red lines represent the warm North Atlantic waters carried by the Norwegian Atlantic Current (NAC) and West Spitsbergen Current (WSC). The blue lines represent the cold Arctic waters carried by the East Spitsbergen Current (ESC). The dotted yellow line represents the polar front (PF). Bathymetry was obtained from EMODnet (http://portal.emodnet-bathymetry.eu, last access: 24 January 2019), and the map was elaborated with QGIS (made with Natural Earth). (b) Longitudinal bathymetric profile sketches showing seasonal formation and flow of brine in inner and outer Storfjorden (modified from Skogseth et al., 2005a and Rasmussen and Thomsen, 2015) and the indicative location of the sampling stations (red dots).

ern coast of Norway, and (ii) the West Spitsbergen Current (WSC), which flows northwards along the western Svalbard coast towards the Fram Strait (Schauer, 1995). Recent studies report fluctuations in heat transport to the Arctic Ocean by the WSC in particular that are linked with global climate change (e.g. Holliday et al., 2008; Piechura and Walczowski 2009; Beszczynska-Moller et al., 2012). This current is playing a significant role in the process of recent Arctic warming by influencing sea ice distribution and cover in Svalbard (Polyakov et al., 2012).

The water masses in Storfjorden have two main origins: warm Atlantic waters and cold Arctic waters. These are mostly separated by the location of the polar front, which shifts seasonally and therefore influences the northward or southward position of these water masses (Loeng, 1991) (Fig. 1a). The warm Atlantic surface waters carried by the NAC enter the Storfjordrenna from the southwest (Wekerle et al., 2016) (Fig. 1a). During spring-summer, this latter flows into Storfjorden along its eastern margin follow- ing a cyclonic circulation (Nielsen and Rasmussen, 2018; Piechura and Walczowski, 2009). The cold Arctic waters derived from the ESC enter Storfjorden from the east through narrow topographic gateways (Heleysundet and Freemansundet sounds) and the topographic depression north of Storfjordbanken (Fig. 1a). This Arctic water circulates cyclonically through the fjord, flowing southwards along the western Storfjorden coast and continuing northwards as a coastal current along the west Spitsbergen coast (Nielsen and Rasmussen, 2018; Rasmussen and Thomsen, 2015). Vertically, water masses are usually arranged in three main layers within an Arctic fjord with a sill (Farmer and Freeland, 1983): a relatively fresh surface layer, a deep and saline layer below the sill depth, and an intermediate layer in between (Fig. 1b). Profiles from late summer in Storfjorden show a well-mixed fresh surface layer extending down to $40 \mathrm{~m}$ depth separated from the intermediate layer (comprising advected Atlantic Water) by a steep halocline. The deepest layer, which sits below the sill depth, is a cold and saline water mass derived 
from trapped brine (e.g. Skogseth et al., 2005a; Cottier et al., 2010; Rasmussen and Thomsen, 2015).

The shelf sea in the Storfjorden is characterised by an extended winter first-year sea ice cover due to the presence of a recurrent winter coastal latent-heat polynya mostly located in the northeastern part (Skogseth et al., 2004). Polynyas are ice-free areas formed and maintained by advection of ice by offshore winds and tidal and ocean currents. The presence of northerly winds allows for the development of the polynya, while southerly winds cause the polynya to shrink, which makes the extension and the position of the polynya highly variable (Haarpaintner et al., 2001b). The opening of a latent-heat polynya determines an intensive heat loss to the atmosphere that can lead to a persistent ice formation (Fer et al., 2004; Skogseth et al., 2005a). Polynya particularly occurs when northeasterly winds intensify in winter (Skogseth et al., 2004). The continuous production of thin, first-year sea ice, which generally starts in December (Smedsrud et al., 2006), leads to a subsequent formation of brine waters in Storfjorden. Brines are cold, dense and well-oxygenated waters, enriched in salt and total dissolved inorganic carbon (DIC) (i.e. low $\mathrm{pH}$ ), that are rejected in undersea ice waters when sea ice is formed (Rysgaard et al., 2011; Anderson et al., 2004). The shelf convection promotes the mixing of brine with shelf waters, leading to the formation of brineenriched shelf waters (BSW). In the early winter freezing period, the extremely dense BSW sink, filling the deeper basins and pushing the less dense waters above the sill level, causing a weak overflow (Skogseth et al., 2005a) (Fig. 1b). During winter the low temperature causes a brine volume contraction and a decrease in the sea ice permeability that prevents the air-sea ice gas exchange; brine volume contraction causes a further increase in brine salinity and $\mathrm{CO}_{2(\mathrm{aq})}$ (Rysgaard et al., 2011). The continuous freezing in spring causes the accumulation of BSW in the deep basins and a strong steady overflow period over the sill. Although weaker, the overflow continues even in summer after the end of the freezing period. In the meantime, the fresh melting surface water is warmed by surface heating (Skogseth et al., 2005a). During spring and summer, the ice melting reduces $\mathrm{CO}_{2(\mathrm{aq})}$ (Rysgaard et al., 2011) and the increase in light availability (Horner and Schrader, 1982) triggers ice algae photosynthetic activity, which further reduces DIC concentrations of surface waters (Gleitz et al.,1995). In autumn, surface waters lose heat and become colder. At this time, the old BSW are trapped in the deep basins, but strong wind events cause occasional discharges over the sill (Skogseth et al., 2005a) (Fig. 1b). All Arctic coastal polynyas together produce about $0.7-1.2 \mathrm{~Sv}\left(1 \mathrm{~Sv}=10^{6} \mathrm{~m}^{3} \mathrm{~s}^{-1}\right)$ of BSW (Cavalieri and Martin, 1994), providing about $10 \%$ of the deep water formed in the Arctic Ocean and Barents Sea today (Smethie et al., 1986; Quadfasel et al., 1988; Rudels and Quadfasel, 1991). Storfjorden is a major supplier of BSW, alone producing 5$10 \%$ of the dense water in the Arctic Ocean (Quadfasel et al., 1988; Smedsrud et al., 2006).
Spitsbergen is characterised by the presence of several tidewater glaciers influencing the head of the Storfjorden (see Fig. 9 in Lydersen et al., 2014). Ongoing climate warming has been causing the retreat of several glaciers present on Svalbard over the last 100 years, increasing sediment supply and accumulation (Zajączkowski et al., 2004). In this context, Winkelmann and Knies (2005) classified the inner Storfjorden as a low-energy environment characterised by high sedimentation rates and organic-rich sediments (total organic carbon content $(\mathrm{TOC})>2 \%$ ) with a high proportion of terrestrial components.

\section{Material and methods}

\subsection{Interface sediment sampling and CTD profiles}

In July 2016, seven stations were sampled along a northsouth transect in Storfjorden (Fig. 1a, Table 1) during the STeP (Storfjorden Polynya Multidisciplinary Study) cruise on board the R/V L'Atalante (IFREMER). Stations MC1 to MC3 are positioned on the continental shelf at the head of the fjord, stations MC4 and MC5 are located in the deep central basins, station MC6 is located on the sill, and station MC7 is located in the Storfjordrenna (Fig. 1a, Table 1). At each station, 10 to $40 \mathrm{~cm}$ long sediment cores were sampled using a multi-corer $(10 \mathrm{~cm}$ inner diameter $)$ in order to get undisturbed sediment-water interfaces. Three replicate cores were sampled at each station (except for station MC3 where only two cores were collected): the first core for geochemical analysis (oxygen, $\mathrm{pH}$ and porosity profiles); the second for ${ }^{210} \mathrm{~Pb}_{\mathrm{xs}}$ dating, grain size, phytopigment, and organic matter analyses; and the third for foraminiferal analysis.

In order to determine the main environmental characteristics of each site, hydrographic casts were performed with a conductivity-temperature-depth sensor (Seabird 911 plus CTD) equipped with a fluorometer. A rosette sampler supplied with $22 \times 12 \mathrm{~L}$ Niskin bottles was used for water column sampling. Bottles were fired at standard depths to measure oxygen, nutrients and Chlorophyll $a$.

\subsection{Geochemical analyses}

Immediately after the recovery of sediment cores, oxygen and $\mathrm{pH}$ microprofiles were measured at the sedimentwater interface. We used a micromanipulator that can drive $\mathrm{O}_{2}$ and $\mathrm{pH}$ microelectrodes (Unisense ${ }^{\circledR}$ ) at the same time with a $200 \mu \mathrm{m}$ vertical resolution. Oxygen profiles were performed using Clark-type microelectrodes with a $100 \mu \mathrm{m}$ thick tip (Revsbech 1989), while $\mathrm{pH}$ profiles were measured using a glass microelectrode with a $200 \mu \mathrm{m}$ thick tip. The $\mathrm{O}_{2}$ concentration of bottom water was analysed by Winkler titration (Grasshoff et al., 1983). At each station, triplicate samples were analysed with a reproducibility of $\pm 2 \mu \mathrm{mol} \mathrm{L}^{-1}$. The $\mathrm{pH}$ microelectrodes were calibrated using National $\mathrm{Bu}$ reau of Standards (NBS) buffer solutions ( $\mathrm{pH} \mathrm{4,} 7$ and 10). 
Table 1. Geographic coordinates, depths of the seven studied stations and bottom water parameters (temperature and salinity are measured in situ by the CTD, $\mathrm{O}_{2}$ (dissolved oxygen) and $\mathrm{pH}_{\mathrm{T}}$ are measured from Niskin bottles).

\begin{tabular}{lcrrrrrrrr}
\hline $\begin{array}{l}\text { Sampling } \\
\text { date }\end{array}$ & Station & $\begin{array}{r}\text { Latitude } \\
(\mathrm{N})\end{array}$ & $\begin{array}{r}\text { Longitude } \\
(\mathrm{E})\end{array}$ & $\begin{array}{r}\text { Depth } \\
(\mathrm{m})\end{array}$ & $\begin{array}{r}\text { Temperature } \\
\left({ }^{\circ} \mathrm{C}\right)\end{array}$ & Salinity & $\begin{array}{r}\text { Density } \\
\left(\mathrm{kg} \mathrm{m}^{-3}\right)\end{array}$ & $\mathrm{pH}_{\mathrm{T}}$ & $\begin{array}{r}\mathrm{O}_{2} \\
\left(\mu \mathrm{mol} \mathrm{L}^{-1}\right)\end{array}$ \\
\hline 13 July 2016 & MC1 & $78^{\circ} 15.0$ & $19^{\circ} 30.0$ & 108.0 & -1.74 & 34.89 & 1028.59 & 8.00 & 341 \\
14 July 2016 & MC2 & $77^{\circ} 50.0$ & $18^{\circ} 48.0$ & 117.0 & -1.59 & 34.79 & 1028.52 & 7.95 & 317 \\
14 July 2016 & MC3 & $77^{\circ} 58.6$ & $20^{\circ} 14.6$ & 99.0 & 1.10 & 34.74 & 1028.29 & 8.12 & 350 \\
15 July 2016 & MC4 & $77^{\circ} 29.2$ & $19^{\circ} 10.6$ & 191.5 & -1.78 & 34.92 & 1029.01 & 7.92 & 319 \\
17 July 2016 & MC5 & $77^{\circ} 13.2$ & $19^{\circ} 17.9$ & 171.0 & -1.78 & 34.93 & 1028.91 & 7.91 & 317 \\
18 July 2016 & MC6 & $76^{\circ} 53.9$ & $19^{\circ} 30.3$ & 157.0 & -1.13 & 34.80 & 1028.72 & 7.97 & 317 \\
19 July 2016 & MC7 & $76^{\circ} 00.9$ & $17^{\circ} 03.4$ & 321.0 & 3.53 & 35.05 & 1029.33 & 8.04 & 305 \\
\hline
\end{tabular}

The $\mathrm{pH}$ of bottom water was also determined by spectrophotometry using m-Cresol Purple as dye (Dickson et al., 2007). All $\mathrm{pH}$ measurements were recalculated at in situ temperature, salinity and depth using CO2SYS (Pierrot et al., 2006) and were reported on the total proton scale $\left(\mathrm{pH}_{\mathrm{T}}\right)$. The measurements for both $\mathrm{O}_{2}$ and $\mathrm{pH}$ profiles, were repeated many times in order to assess the reproducibility of the measurements and the natural heterogeneity of these parameters in the sediment.

\subsection{Grain size analysis and ${ }^{210} \mathrm{~Pb}$ dating}

At each station (except for the MC3), one core was sliced on board, collecting five sediment layers $(0-0.5,0.5-1,1-2$, $2-5$ and $5-10 \mathrm{~cm}$ ), then stored at $-20^{\circ} \mathrm{C}$. In the land-based laboratory, an aliquot of sediment was sampled for grain size analyses and the rest was lyophilised for the ${ }^{210} \mathrm{~Pb}_{\mathrm{xs}}$ analyses. Grain size analyses were performed using the laser diffraction particle size analyser Malvern Mastersizer 3000. The particle size distributions were analysed with GRADISTAT 8.0 software program (Blott and Pye, 2001). Replicated analyses were run for each sample aliquot and the most representative was selected. For the analysis of fauna in response to environmental parameters, the grain size of the superficial sediment layer $(0.0-0.5 \mathrm{~cm}$ depth$)$ was considered representative of the sediment-water interface characteristics. Another aliquot of sediment was freeze-dried for gamma spectrometry measurements in order to determine the apparent sedimentation rate by the ${ }^{210} \mathrm{~Pb}_{\mathrm{xs}}$ method (Appleby and Oldfield, 1978). The ${ }^{210} \mathrm{~Pb}$ dating was conducted using a gamma spectrometer Canberra ${ }^{\circledR}$ HPGe GX4520 coaxial photon detector. The homogenised samples were weighed and sealed in a defined geometry for at least 3 weeks to ensure ${ }^{222} \mathrm{Rn}-$ ${ }^{226} \mathrm{Ra}-{ }^{214} \mathrm{~Pb}$ equilibration. Sedimentation rate was based on the determination of the excess or unsupported activity ${ }^{210} \mathrm{~Pb}\left({ }^{210} \mathrm{~Pb}_{\mathrm{xs}}\right)$ and performed through constant fluxconstant sedimentation (CFCS) model (Sanchez-Cabeza and Ruiz-Fernández, 2012). The ${ }^{210} \mathrm{~Pb}_{\mathrm{xs}}$, incorporated rapidly into the sediment from atmospheric fallout and water column scavenging, was calculated as the difference between the total measured ${ }^{210} \mathrm{~Pb}$ activity (supported + excess) at $46.54 \mathrm{keV}$ and ${ }^{214} \mathrm{~Pb}$ at $351.93 \mathrm{keV}$.

\subsection{Organic matter quantity and biochemical composition}

To assess the quantity and biochemical composition of the organic matter, the top $0.5 \mathrm{~cm}$ of the sediment cores was sliced on board and immediately stored at $-20^{\circ} \mathrm{C}$ until analysis. As the redox fronts and foraminiferal microhabitats in the sediment are strictly driven by the organic matter supply at the sediment-water interface (e.g. Jorissen et al., 1995), only the organic matter data for the upper $0.5 \mathrm{~cm}$ were used to interpret the faunal distribution.

In the laboratory, chlorophyll $a(\mathrm{Chl} a)$, phaeopigment, lipid (LIP), carbohydrate (CHO) and protein (PRT) contents were determined on three pseudo-replicates (ca. $1 \mathrm{~g}$ wet sediment). Chlorophyll $a$ and phaeopigment analyses were carried out according to Lorenzen and Jeffrey (1980). Briefly, pigments were extracted with $90 \%$ acetone $(12 \mathrm{~h}$ in the dark at $\left.4{ }^{\circ} \mathrm{C}\right)$. After the extraction, the pigments were fluorometrically analysed to estimate the quantity of $\mathrm{Chl} a$ and, after acidification (20s) with $0.1 \mathrm{~N} \mathrm{HCl}$ (Plante-Cuny, 1974), to estimate the amount of phaeopigments. Chloroplastic pigment equivalents (CPE) were calculated as sum of $\mathrm{Chl} a$ and phaeopigment contents, and carbon associated with $\mathrm{CPE}(\mathrm{C}$ CPE) was calculated by converting CPE contents into carbon equivalents using a factor of $30 \mu \mathrm{gC}$ per $\mu \mathrm{g}$ of phytopigment (de Jonge, 1980). Protein, carbohydrate and lipid sedimentary contents were determined by spectrophotometry (Danovaro, 2009) and concentrations reported as bovine serum albumin, glucose and tripalmitin equivalents (mg per gram of dry weight sediment), respectively. Protein, carbohydrate and lipid concentrations were converted into carbon equivalents using the conversion factors $0.49,0.40$ and $0.75 \mathrm{~g} \mathrm{Cg}^{-1}$, respectively (Fabiano et al., 1995). The sum of protein, carbohydrate and lipid carbon was referred to as biopolymeric carbon (BPC; Tselepides et al., 2000) that represents the semi-labile fraction of the total organic carbon (Pusceddu et al., 2009; Van Oevelen et al., 2011). The algal fraction of biopolymeric $\mathrm{C}$, a proxy for the most labile frac- 
tion of sedimentary organic matter (Pusceddu et al., 2003, 2010) was calculated as the percentage ratio of C-CPE in BPC.

\subsection{Living foraminiferal fauna sampling and analyses}

Immediately after sampling, interface cores were sliced horizontally every $0.5 \mathrm{~cm}$ between 0 and $2 \mathrm{~cm}$, every $1 \mathrm{~cm}$ from 2 down to $6 \mathrm{~cm}$, and every $2 \mathrm{~cm}$ from 6 to $10 \mathrm{~cm}$ depth. Each slice was stored in a $500 \mathrm{~cm}^{3}$ plastic bottle filled with $95 \%$ ethanol containing $2 \mathrm{gL}^{-1}$ of rose bengal stain (in order to label living foraminifera) following the FOBIMO directive (Schönfeld et al., 2012). In the laboratory, sediment samples were sieved through 63,125 and $150 \mu \mathrm{m}$ meshes, and the resulting fractions were stored in $95 \%$ ethanol. All living (rose bengal-stained) specimens from the $>150 \mu \mathrm{m}$ fraction were hand-picked in water from the surface layer down to $5 \mathrm{~cm}$ depth. Additionally, the living foraminifera of the $63-150 \mu \mathrm{m}$ fraction were picked only for the first centimetre of sediment, in order to investigate the potential use of this size fraction for ecological consideration. We counted only the specimens with bright rose staining (assessing the colouration intensity of living specimens for every individual species, as recommended by Schönfeld et al., 2012) as living foraminifera.

Samples of the smallest size fraction, showing very high benthic foraminiferal abundance, were dried at $50^{\circ} \mathrm{C}$ and split with an Otto Microsplitter. Then foraminifera were hand-sorted from an entire split containing a minimum of 300 individuals and the counts were extrapolated for the total sample. Foraminiferal biodiversity was estimated using different diversity indices: species richness measured as the number of species, species diversity measure using the Shannon-Wiener Index $\left(H^{\prime}\right)$ and species equitability $(J)$ measured using the "Pielou Index (1975)". All indices were calculated using the Paleontological Statistics Data Analysis (PAST) software (version 2.17c; Hammer et al., 2001). Foraminiferal densities are expressed per $50 \mathrm{~cm}^{2}$ (when considering total densities) and per $50 \mathrm{~cm}^{3}$ (when considering layers of different thickness). The agglutinated species Spiroplectammina earlandi and Spiroplectammina biformis were not distinguished because these are morphotypes of the same species according to Korsun and Hald (2000).

\subsection{Multivariate analyses}

A canonical correspondence analysis (CCA) was used to investigate the relationships between the environmental parameters (depth, bottom water temperature, salinity, oxygen penetration depth or OPD, sediment porewater $\mathrm{pH}$, sediment grain size, and organic matter) and the fauna $(>150 \mu \mathrm{m}$, $0-5 \mathrm{~cm}$ ) of all stations considering only the absolute densities (ind. $50 \mathrm{~cm}^{-2}$ ) of the species which contribute with $>$ $5 \%$ to the assemblage. We used the grain size characteristics and the organic matter contents and composition of the uppermost sediment layer $(0.0-0.5 \mathrm{~cm})$. Values of differ- ent environmental variables and different orders of magnitude were homogenised using the following standardisation: $(x-$ mean $x) / \mathrm{SD}$, in which $x$ is the value of the variable at one station, mean $x$ is the mean of the same variable among the stations and SD is the corresponding standard deviation. Non-metric multidimensional scaling (nMDS) bi-plot and cluster analyses (Bray-Curtis similarity) were used to visualise the differences among stations and size fractions. The analyses were conducted on the foraminiferal assemblages of the topmost centimetre of sediment separately considering the smaller fraction $63-150 \mu \mathrm{m}$, the $>150 \mu \mathrm{m}$ fraction and the total assemblage ( $>63 \mu \mathrm{m}$ fraction). The densities of the foraminiferal fauna were normalised using the following transformation: $\log _{10}(x+1)$, where $x$ is the density expressed in ind. $50 \mathrm{~cm}^{-2}$ (considering the $0-5 \mathrm{~cm}$ sediment interval for the CCA and the $0-1 \mathrm{~cm}$ interval for the nMDS and cluster analysis). All analyses were performed using the PAST software (version 2.17c; Hammer et al., 2001).

\subsection{Visual characterisation of test dissolution}

Using high-resolution scanning electron microscope (SEM) images of specimens from the $>150 \mu \mathrm{m}$ size fraction (Fig. S2 in the Supplement), we qualitatively distinguish four dissolution stages from weak to severe, following the classification of Gonzales et al. (2017): (I) no sign of dissolution, transparent tests and smooth surfaces; (II) whitish tests with visible pores, where frequently the last chamber is lost in addition to the first calcite layers; (III) several chambers are dissolved and the remaining ones present opaque wall tests; and (IV) nearly complete dissolution of the tests, and only the organic material remains. The percentage of specimens belonging to each of the four stages in all samples was not quantified because of the potential loss of information due to the bad preservation characterising the two most severe dissolution stages.

\section{Results}

\subsection{Bottom water properties}

In July 2016, bottom waters at the inner fjord stations $\mathrm{MC} 1$ and $\mathrm{MC} 2$ are cold (below $-1.5^{\circ} \mathrm{C}$ ) and relatively salty (34.89 and 34.79 , respectively), while station MC3 presents a positive bottom water temperature $\left(1.10^{\circ} \mathrm{C}\right)$, the lowest salinity (34.74), and the highest $\mathrm{pH}_{\mathrm{T}}$ (8.12) and $\mathrm{O}_{2}$ $\left(350 \mu \mathrm{mol} \mathrm{L}^{-1}\right)$ of the fjord transect (Table 1). The two deep basin stations (MC4 and MC5) display the lowest bottom water temperature (both $-1.78^{\circ} \mathrm{C}$ ), the lowest $\mathrm{pH}_{\mathrm{T}}(7.92$ and 7.91, respectively) and the highest salinity (34.92 and 34.93, respectively) (Table 1). The sill station MC6 shows the same range of salinity than in the inner fjord (34.80) with a slightly higher temperature $\left(-1.13^{\circ} \mathrm{C}\right)$. The outer fjord station MC7 records the highest temperature $\left(3.53^{\circ} \mathrm{C}\right)$ and salinity $(35.05)$ of the sampled transect. The shallowest stations (MC1 and 
MC3) are well ventilated, with $\mathrm{O}_{2}$ concentrations higher than $340 \mu \mathrm{mol} \mathrm{L}^{-1}$. Stations MC2, MC4, MC5 and MC6 show the same bottom water $\mathrm{O}_{2}$ concentration $\left(318 \pm 2 \mu \mathrm{mol} \mathrm{L}{ }^{-1}\right)$. The deepest station (MC7), located outside Storfjorden, shows a lower $\mathrm{O}_{2}$ concentration $\left(305 \mu \mathrm{mol} \mathrm{L}^{-1}\right)$.

\subsection{Grain size analysis and sedimentation rate}

The ${ }^{210} \mathrm{~Pb}$ age models show a relatively high sedimentation rate at all stations, with an average of $3.6 \pm 0.4 \mathrm{~mm} \mathrm{yr}^{-1}$ (see Supplement, Table S1 for more details), except at the outer fjord station MC7 where sedimentation rate is much lower $\left(1.3 \pm 0.6 \mathrm{~mm} \mathrm{yr}^{-1}\right.$; Table S1).

Grain size analyses of the topmost $0.5 \mathrm{~cm}$ of the sediment indicate the dominance of silt sediments at all stations (around $84 \%$ to $89 \%$, Table S1). Slight differences are, however, noted in terms of the mode: in the fjord fine silt $(\sim 10 \mu \mathrm{m})$ is dominant, while in the outer station MC7 the mode corresponds to medium silt $(\sim 20 \mu \mathrm{m})$. Moreover, the percentage of sand increases from approximately $4.0 \%$ at MC1 to $10.4 \%$ at station MC6 and declines to $6.8 \%$ at MC7.

\subsection{Biogeochemical analyses of the sediment}

The sediment oxygen profiles (Fig. S1a) at the inner fjord stations (MC1 to MC3) display an average oxygen penetration depth (OPD) of $7.7 \pm 1.0 \mathrm{~mm}(n=3), 4.9 \pm 0.4 \mathrm{~mm}(n=4)$ and $4.8 \pm 1.9 \mathrm{~mm}(n=6)$, respectively. The OPD at the deep basin stations (MC4 and MC5) and at the sill station (MC6), are $5.7 \pm 1.1 \mathrm{~mm}(n=3), 6.2 \pm 0.9(n=10)$ and $8.6 \pm 3.8$ $(n=6)$, respectively. The outer fjord station (MC7) shows the highest OPD of the sampled transect $(15.6 \pm 1.0 \mathrm{~mm}$, $n=6)$.

The porewater $\mathrm{pH}_{\mathrm{T}}$ at the sediment-water interface $(\mathrm{pH}$ profiles in Fig. S1b) is significantly different among the stations (one-way ANOVA, $F=128.8, p<0.001$ ). The inner fjord stations (MC1 to MC3), the sill (MC6) and outer fjord (MC7) have $\mathrm{pH}_{\mathrm{T}}$ values generally above 7.95 , significantly different (Tukey's HSD post hoc test, $p<0.001$ ) from the deep basin stations which have $\mathrm{pH}_{\mathrm{T}}$ values less than or equal to 7.90. When considering the entirety of the profiles, $\mathrm{pH}$ strongly decreases in the topmost part of the sediment $(0-$ $5 \mathrm{~mm}$ ) at all stations but with different slopes. The gradients of the two extremes are $-0.2 \mathrm{pH}$ unit per millimetre at station MC3 and $-0.1 \mathrm{pH}$ unit $\mathrm{mm}^{-1}$ at MC7 (see Fig. S1b).

Concerning the organic matter, the results for BPC, PRT, $\mathrm{CHO}$, LIP, and CPE content and algal fraction of BPC (C$\mathrm{CPE} / \mathrm{BPC}$ are presented in Fig. 2. The complete dataset is reported as average \pm standard deviation $(n=3)$ in Table S2 of the Supplement. The BPC (Fig. 2a) varies significantly among the stations (one-way ANOVA, $F=21.72$, $p<0.001)$. Stations MC1 and MC7 have values of BPC significantly lower $\left(5.49 \pm 0.49\right.$ and $4.71 \pm 0.07 \mathrm{mg} \mathrm{Cg}^{-1}$, respectively, Tukey's HSD $p<0.05$ ) than at all other stations.
In the latter, the average BPC varies between $6.86 \pm 0.45$ and $7.38 \pm 0.21 \mathrm{mg} \mathrm{Cg}^{-1}$. The PRT contents (\%) (Fig. 2a) of the BPC varies significantly among the stations (one-way ANOVA, $F=6.94, p<0.01)$. In particular, the deep basins present significantly lower percentages of PRT compared to all the other stations $(32.12 \pm 4.42 \%$ at MC4 and $30.75 \pm$ 4.58 at MC5; Tukey's HSD $p<0.01)$. The CHO contents (\%) (Fig. 2a) change significantly among the stations (oneway ANOVA; $F=46.6 ; p<0.001)$, displaying the highest scores in the deep basins $(33.79 \pm 1.71 \%$ and $36.08 \pm 2.52 \%$ at MC4 and MC5, respectively). The CPE (Fig. 2b) varies significantly among the stations (one-way ANOVA, $F=$ 52.03, $p<0.001)$. CPE content is considerably lower in the outer fjord station MC7 $\left(6.43 \pm 0.45 \mu \mathrm{gg}^{-1}\right)$ compared to all other stations $(p<0.001)$. Inside the fjord, station MC1 differs from MC2, with values of $24.04 \pm 3.69$ and $41.19 \pm$ $9.62 \mu \mathrm{g} \mathrm{g}^{-1}$, respectively (Tukey's HSD $p=0.02$ ), whereas all other CPE contents present intermediate values. The CCPE / BPC (Fig. 2b) in the uppermost $0.5 \mathrm{~cm}$ varies significantly among the stations (one-way ANOVA, $F=76.82$, $p<0.001)$. In particular, the algal fraction is significantly lower in the outer fjord station MC7 $(4.09 \pm 0.33 \%)$ compared to all other stations (Tukey's HSD $p<0.001$ ). On the contrary, all the stations inside the fjord do not differ significantly and have values between $13 \%$ and $17 \%$.

\subsection{Foraminiferal assemblages of the $0-5 \mathrm{~cm}$ sediment layer ( $>150 \mu \mathrm{m}$ fraction)}

\subsubsection{Abundances and diversity}

Considering the total foraminiferal fauna in the $0-5 \mathrm{~cm}$ sediment interval (Table 2), the highest absolute abundance is displayed at the inner fjord station MC2 (2249 ind. $50 \mathrm{~cm}^{-2}$ ), whereas it is reduced by about half at the other two inner fjord stations (1104 and 1353 ind. $50 \mathrm{~cm}^{-2}$ at MC1 and MC3, respectively). The absolute abundance increases at the deep basin stations (1861 and 1439 ind. $50 \mathrm{~cm}^{-2}$ at $\mathrm{MC} 4$ and MC5, respectively) and drastically declines at the sill station MC6, reaching the lowest abundance detected in the transect (940 ind. $50 \mathrm{~cm}^{-2}$ ). At the outer fjord station MC7, the total absolute abundance is 1238 ind. $50 \mathrm{~cm}^{-2}$.

The inner fjord stations MC1 and MC2 present the same number of species (27) (Table 2) and similar ShannonWiener index $\left(H^{\prime}=1.61\right.$ and 1.48$)$ and equitability $(J=$ 0.49 and 0.45 ). The third inner fjord station MC3 is characterised by the lowest diversity $\left(19\right.$ species and $\left.H^{\prime}=0.92\right)$ and the lowest equitability $(J=0.31)$, whereas the deep basin stations MC4 and MC5 show relative high $H^{\prime}(2.25$ and 2.35 , respectively) and $J$ values $(0.62$ and 0.70 , respectively). The sill station MC6 shows similar $H^{\prime}$ and $J$ values compared to the deep basin stations $(2.18$ and 0.65 , respectively). The outer fjord station MC7 shows the highest number of species (44) and $H^{\prime}$ index (2.40). 


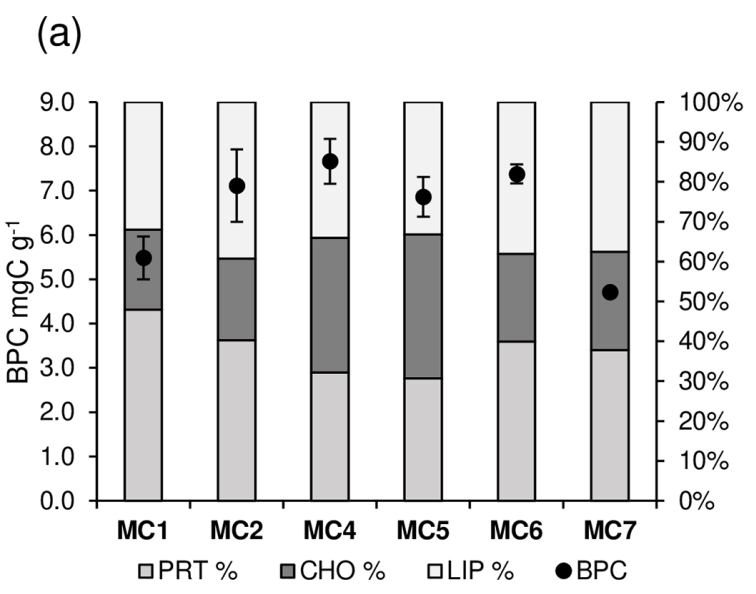

(b)

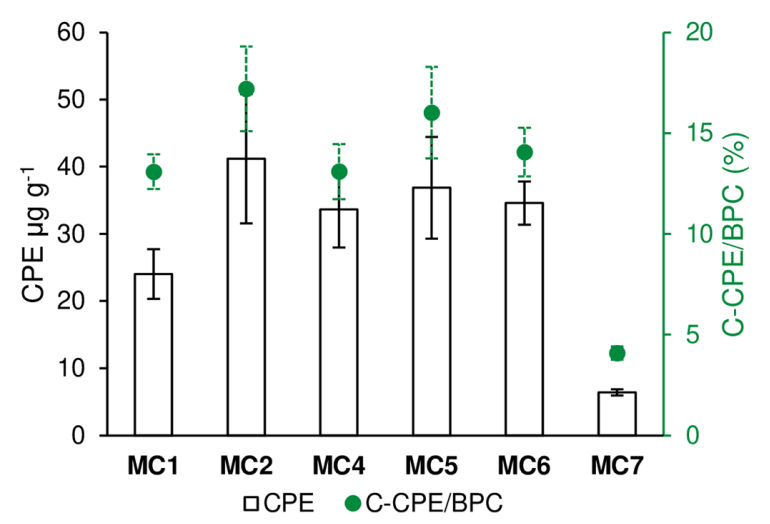

Figure 2. For each sampling station the following information is shown (data are not available at station MC3): (a) content of biopolymeric carbon (BPC, black dots) and percentage of protein, carbohydrate, and lipid content (cumulative bars) and (b) the content of chloroplastic pigment equivalents (CPE, white bars) and algal fraction of BPC (C-CPE / BPC, green dots).

Table 2. Foraminiferal total abundances (in number of individuals per $50 \mathrm{~cm}^{2}$ ) and diversity indexes, considering the total living fauna ( $>150 \mu \mathrm{m}$ size fraction) in the 0 to $5 \mathrm{~cm}$ core top sediment.

\begin{tabular}{lccccccc}
\hline Stations & MC1 & MC2 & MC3 & MC4 & MC5 & MC6 & MC7 \\
\hline $\begin{array}{l}\text { Abundance } \\
\text { (ind. } 50 \mathrm{~cm}^{-2} \text { ) }\end{array}$ & 1104 & 2249 & 1353 & 1861 & 1439 & 940 & 1238 \\
\hline $\begin{array}{l}\text { Species } \\
\text { richness }\end{array}$ & 27 & 27 & 19 & 37 & 29 & 29 & 44 \\
\hline $\begin{array}{l}\text { Shannon-Wiener } \\
\left(H^{\prime}\right)\end{array}$ & 1.61 & 1.48 & 0.92 & 2.25 & 2.35 & 2.18 & 2.40 \\
\hline Equitability $(J)$ & 0.49 & 0.45 & 0.31 & 0.62 & 0.70 & 0.65 & 0.64 \\
\hline
\end{tabular}

In terms of species composition (Fig. 3a), the inner fjord stations are mainly dominated by two calcareous species: Elphidium clavatum, contributing $22 \%, 47 \%$, and $75 \%$ of the total fauna, and Nonionellina labradorica, contributing $51 \%, 31 \%$, and $13 \%$ at $\mathrm{MC} 1, \mathrm{MC} 2$, and $\mathrm{MC} 3$, respec- tively. Cassidulina reniforme is a secondary species at station MC1 (10\%), and Elphidium bartletti is a secondary species at station MC2 (8\%). The deep basin stations (MC4 and MC5) are dominated by various agglutinated species that contribute differently to the total assemblages. The most abundant are Recurvoides turbinatus (12\% and $18 \%$, respectively, at MC4 and MC5), Reophax fusiformis (13\% and $10 \%$ ) and Reophax scorpiurus (27\% and $17 \%$ ). Ammotium cassis and Labrospira crassimargo are less abundant at MC4 compared to MC5 (2\% and $11 \%$ for A. cassis and $6 \%$ and $11 \%$ for $L$. crassimargo, respectively). Additionally, the calcareous $N$. labradorica is still quite abundant (20\% at MC4 and $8 \%$ at MC5). The sill station MC6 shows similarity with the deep basin stations because of the presence of the agglutinated $R$. turbinatus (10\%) and R. fusiformis (24\%) but it differs by the presence of the agglutinated Adercotryma glomeratum (29\%). The outer fjord station (MC7) can be distinguished from all other stations by the exclusive presence of the two calcareous species Globobulimina auriculata and Melonis barleeanus (9\% and $12 \%$, respectively) and by the major contribution of the agglutinated species Lagenammina difflugiformis $(14 \%)$. Nevertheless, some species that are abundant inside the fjord are also present at station MC7 (e.g. N. labradorica $25 \%$, R. fusiformis $6 \%$ and R. scorpiurus $15 \%)$.

\subsubsection{Agglutinated vs. calcareous foraminifera $(0-5 \mathrm{~cm},>150 \mu \mathrm{m})$}

The comparison between the relative abundances of calcareous and agglutinated species, considering the total living fauna in the $0-5 \mathrm{~cm}$ sediment interval (Fig. 3b) shows the strong dominance of calcareous species (between 91 and $94 \%$ ) at the inner fjord stations (MC1, MC2 and MC3). The opposite is observed at the two deep basin stations (MC4 and MC5) and at the sill station (MC6), where the relative abundances of agglutinated foraminifera vary from $65 \%$ to $77 \%$. At the outer fjord station, MC7, calcareous species have higher proportions $(60 \%)$, although they are not as dominant as at the inner fjord stations.

\subsubsection{Vertical distribution}

The foraminiferal absolute density displays an overall decreasing trend from the surface sediment down to $5 \mathrm{~cm}$ depth at all stations (Fig. 4). The superficial layers (0$1 \mathrm{~cm}$ ) of the inner fjord stations (MC1, MC2, MC3; Fig. 4a) are mostly represented by Elphidium clavatum, Cassidulina reniforme (especially at MC1), Nonionellina labradorica and other accessory species (e.g. Triloculina oblonga, Elphidium bartletti, Ammotium cassis). The deeper layers (down to $5 \mathrm{~cm}$ ) show much lower abundances and are increasingly occupied by Nonionellina labradorica.

In the two deep basins (MC4 and MC5; Fig. 4b), four agglutinated species are dominant in the first centimetre of sedi- 


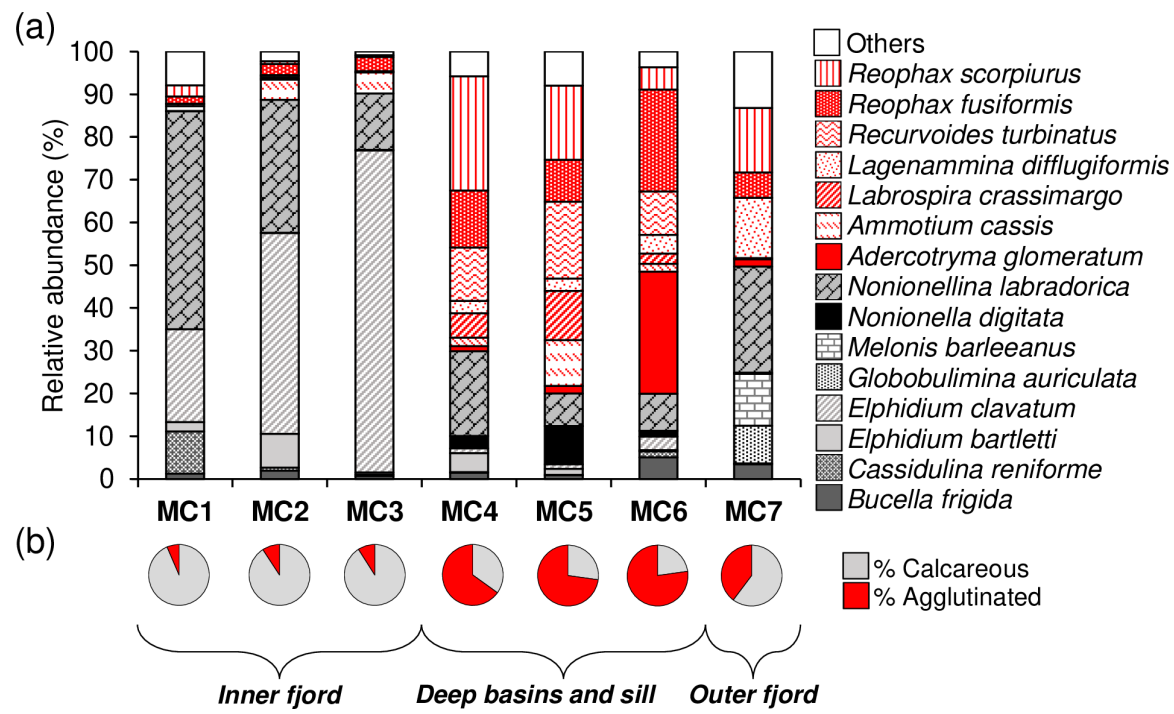

Figure 3. (a) Species relative abundances of the total living fauna ( $>150 \mu \mathrm{m}$ fraction) in the 0 to $5 \mathrm{~cm}$ core top sediment at each station and (b) the agglutinated species (in red) vs. calcareous species (in grey) ratio.

ment: Reophax scorpiurus, Reophax fusiformis, Recurvoides turbinatus and Labrospira crassimargo. At both stations, the infaunal species $N$. labradorica is present in high relative abundance in the $1-3 \mathrm{~cm}$ sediment intervals, together with Nonionella digitata. In the deepest sediment layers $(3-5 \mathrm{~cm})$, $L$. crassimargo, $R$. scorpiurus and $R$. turbinatus are dominant. At the sill station MC6, the dominant species present in the uppermost centimetre are $R$. fusiformis, $R$. turbinatus and Adercotryma glomeratum (Fig. 4b). These species are also present with important abundances in the deeper layers where they are accompanied by $N$. labradorica at the $1-3 \mathrm{~cm}$ depth intervals. At the outer fjord station MC7, the $0-1 \mathrm{~cm}$ sediment intervals show a dominance of $R$. scorpiurus, $R$. fusiformis and L. difflugiformis (Fig. 4c). In the deeper layers, these species are accompanied and gradually replaced by significant abundances of the calcareous species Melonis barleeanus and Globobulimina auriculata.

\subsubsection{Multivariate analysis}

The CCA analysis based on the foraminiferal data $(0$ $5 \mathrm{~cm},>150 \mu \mathrm{m}$, total absolute densities of 15 species, with a relative abundance $>5 \%$ ) and 15 measured environmental variables is presented in Fig. 5. Axes 1 and 2 explain nearly $90 \%$ of the total variance. This multivariate analysis clearly divides the stations into three groups based on the differences determined by the foraminiferal assemblages and the environmental variables. Axis 1 strongly separates station MC7 from the rest of the stations. This difference is mainly determined by bottom water parameters (T, S, pH), OPD, percentage of silt and water depth. The negative correlation between the outer fjord station MC7 and the CPE content and algal fraction distinguishes it from all other stations. Axis 2 clearly divides the other six stations into two groups: the inner fjord group (composed of stations MC1, MC2 and MC3) and the deep basins and sill group (stations MC4 and MC5 and station MC6). This separation is mainly based on the organic matter composition of the sediment. The inner fjord group of stations is positively correlated with the percentage of proteins, whereas the deep basins and sill group is mainly correlated with the percentage of carbohydrates and the biopolymeric carbon content. This group of stations MC4 to MC6 is also positively correlated with the CPE content and the algal fraction of BPC. These three groups are characterised by different foraminiferal assemblages. The calcareous species Cassidulina reniforme, Elphidium clavatum, Nonionellina labradorica, and Elphidium bartletti characterise the inner fjord, whereas three agglutinated species, Labrospira crassimargo, Adercotryma glomeratum, and Recurvoides turbinatus, and one calcareous species, Nonionella digitata, define the deep basins and sill group. Finally, the exclusive presence of the two species, Melonis barleeanus and Globobulimina auriculata, characterise the outer fjord station MC7.

\subsection{Comparison between the 63-150 and $>150 \mu \mathrm{m}$ size fractions $(0-1 \mathrm{~cm})$}

\subsubsection{Abundances and diversity}

Foraminiferal abundances considering the entire $>63 \mu \mathrm{m}$ fraction $(63-150+>150 \mu \mathrm{m}$ fractions) in the topmost centimetre of the sediment are maximal at MC2 and MC4 (4610 and 3936 ind $50 \mathrm{~cm}^{-2}$, respectively), while all other stations present lower values $\left(<3000\right.$ ind. $50 \mathrm{~cm}^{-2}$ ) (Fig. 6a). When considering only the largest fraction $(>150 \mu \mathrm{m})$ at the first centimetre, MC2 (1467 ind. $50 \mathrm{~cm}^{-2}$ ) and MC4 (1132 ind. $50 \mathrm{~cm}^{-2}$ ) still shows the highest abundances followed 

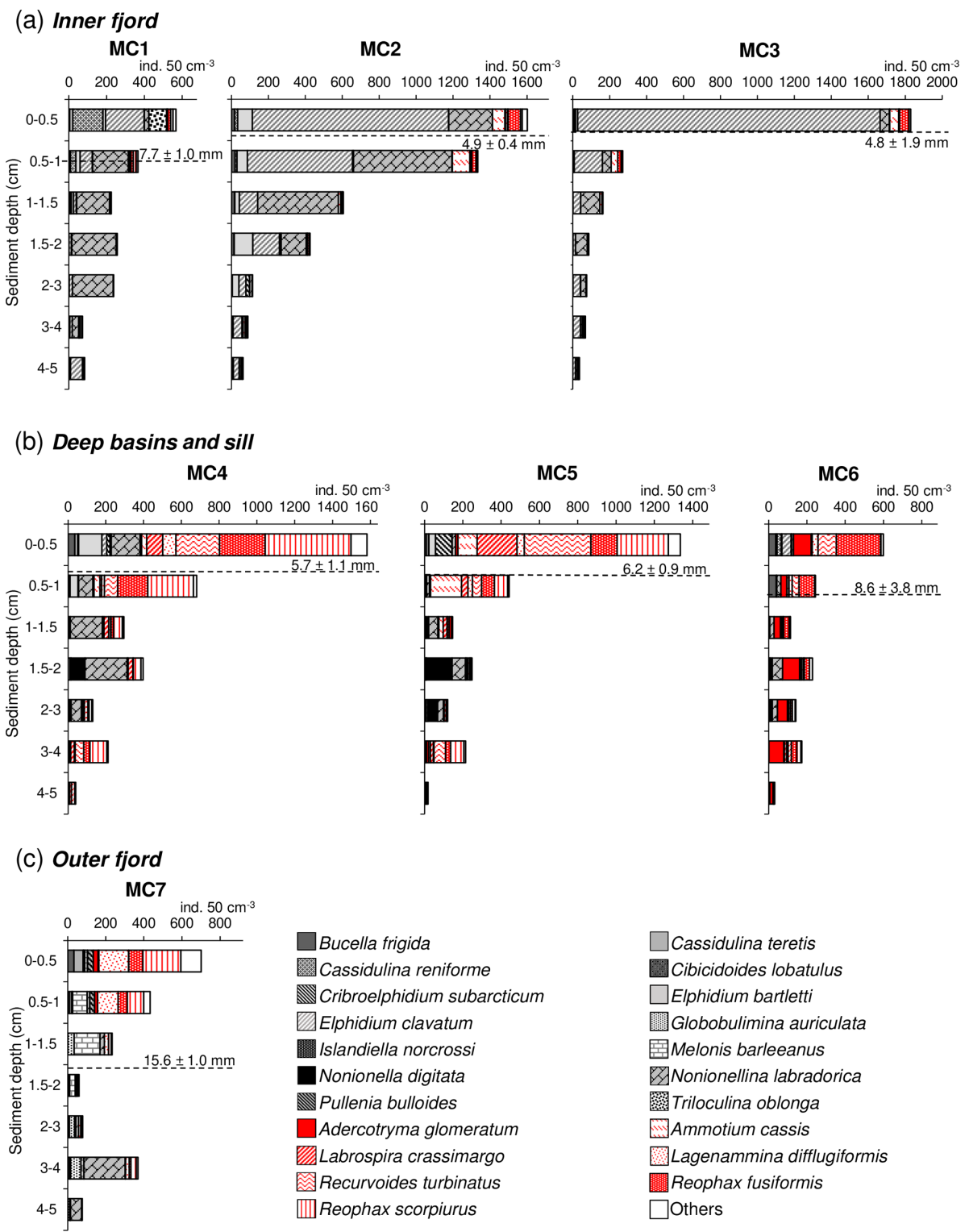

Figure 4. Foraminiferal vertical distribution from 0 to $5 \mathrm{~cm}$ sediment depth (>150 $\mu \mathrm{m}$ fraction) for (a) the inner fjord (stations $\mathrm{MC} 1$ to MC3) (b) deep basins (stations MC4 and MC5) and sill (station MC6), and (c) outer fjord (station MC7). Calcareous species are shown using different grey textures, whereas agglutinated species are shown using different red textures. The dashed black line represents the average oxygen penetration depth (OPD) at each station.

by MC3 and MC5 (1050 and 889 ind. $\left.50 \mathrm{~cm}^{-2}\right)$. For the rest, values are lower than 600 ind. $50 \mathrm{~cm}^{-2}$. The small fraction $(63-150 \mu \mathrm{m})$ is dominant at all stations, contributing with values between $59 \%$ (at MC2) and $83 \%$ (at MC6) to the total abundances.

Regarding diversity values, at MC1 and MC7 no significant differences in the $H^{\prime}$ and $J$ indices are found between the two size fractions (Fig. 6b, c). At stations MC2, MC3 and MC6, $H^{\prime}$ and $J$ values are lower for the $>150 \mu \mathrm{m}$ fraction, whereas the opposite is observed for stations MC4 and MC5, where small size fractions show lower diversity.
In terms of species composition (Fig. 7), the higher diversity of the $63-150 \mu \mathrm{m}$ fraction at stations MC2 and MC3 is due to the additional presence of Stainforthia feylingi, Spiroplectammina biformis and Textularia torquata. However, at this size fraction, as in the $>150 \mu \mathrm{m}$ fraction, the fauna at the three inner fjord stations (MC1, MC2, MC3) is also largely represented by Elphidium clavatum (juveniles) (16\%, $30 \%$ and $66 \%$, respectively). Similarly, juveniles of Cassidulina reniforme are observed in the small fraction at station $\mathrm{MC} 1$ (38\%). At stations MC4 and MC5, the lower diversity of the $63-150 \mu \mathrm{m}$ fraction is due to the strong dominance of 


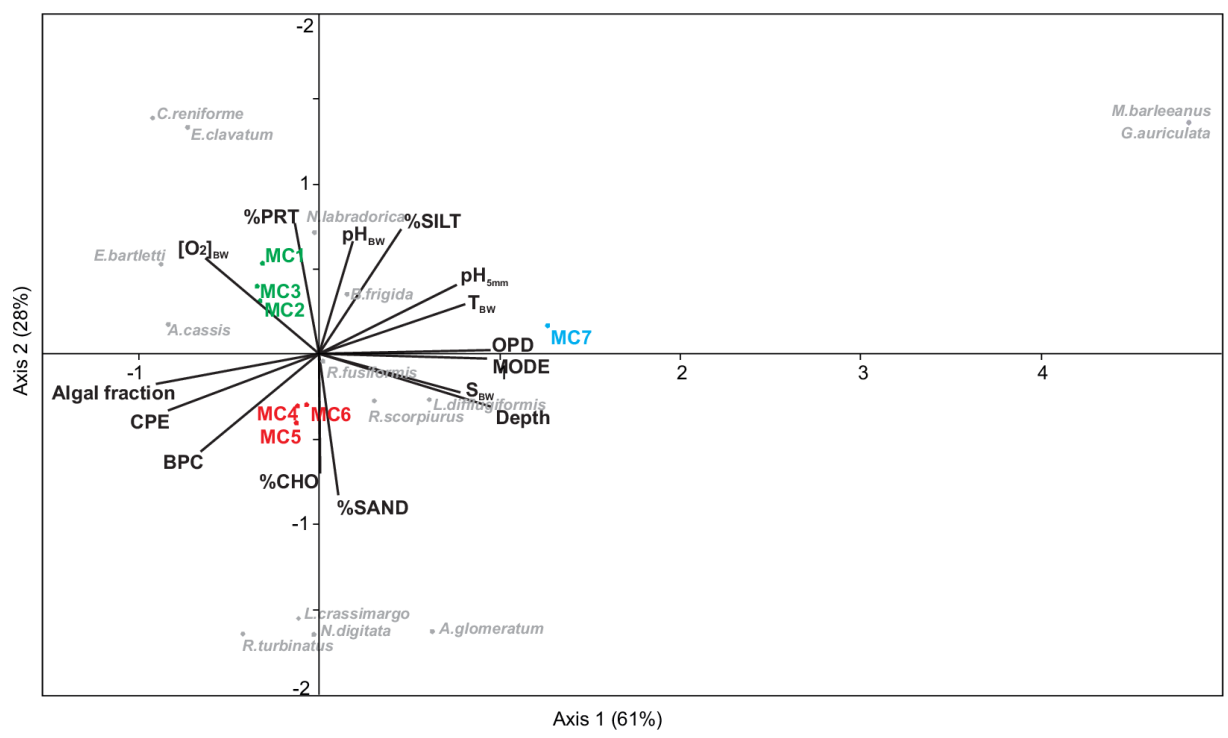

Figure 5. Canonical correspondence analysis based on real abundances (ind. $50 \mathrm{~cm}^{-2}$ ) of the living fauna in the $0-5 \mathrm{~cm}$ sediment layer ( $>150 \mu \mathrm{m}$ size fraction) considering the major species ( $>5 \%$ ) vs. environmental variables described in Tables 1, S1 and S2.

(a)

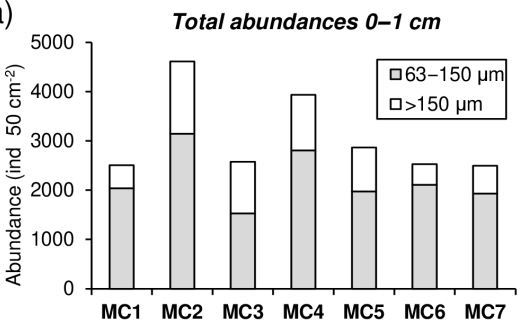

(b)

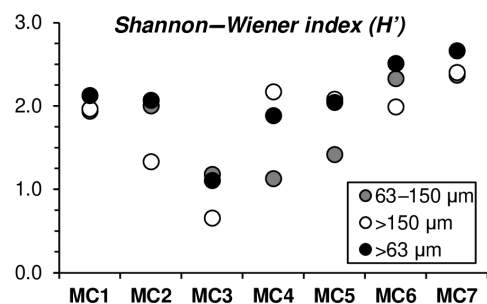

(c)

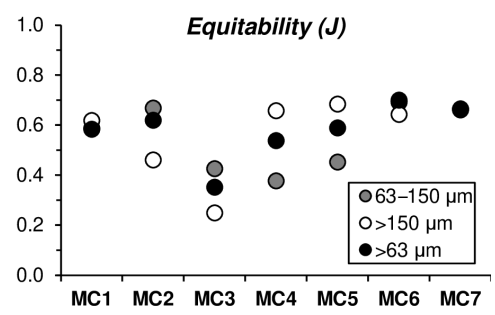

Figure 6. (a) Foraminiferal cumulative abundances (ind. $50 \mathrm{~cm}^{-2}$ ) for two size fractions $(63-150 \mu \mathrm{m}$, grey, and $>150 \mu \mathrm{m}$, white) of the $0-1 \mathrm{~cm}$ sediment layer. (b) Shannon-Wiener $\left(H^{\prime}\right)$ and (c) equitability $(J)$ indexes comparison among the $63-150 \mu \mathrm{m},>150 \mu \mathrm{m}$ and $>63 \mu \mathrm{m}$ (black) fractions.
S. biformis (75\% and $65 \%$, respectively), which is nearly absent in the large size fraction. At station MC7, the small size fraction is characterised by the presence of juveniles of Cassidulina teretis (11\%) and Melonis barleeanus $(8 \%)$, species that are also present in the $>150 \mu \mathrm{m}$ fraction $(5 \%$ and $8 \%$, respectively). These species are accompanied by $C$. reniforme (21\%) and Alabaminella weddellensis (27\%) that are only present in the small size fraction at this site.

\subsubsection{Agglutinated vs. calcareous foraminifera}

The percentage of agglutinated forms is systematically higher in the entire fraction $>63 \mu \mathrm{m}$ compared to the $>$ $150 \mu \mathrm{m}$ at stations MC1 to MC6 (Fig. 8). This is explained by the presence of the small-sized agglutinated species Spiroplectammina biformis and other minor agglutinated species (Cuneata arctica, Textularia torquata, Cribrostomoides sp.). Conversely, the outer fjord station MC7 shows the opposite pattern, mainly because of the presence in the small fraction of calcareous species that are absent in the $>150 \mu \mathrm{m}$ size fraction (i.e. Cassidulina teretis, Cassidulina reniforme, Alabaminella weddellensis).

\subsubsection{Multivariate analyses}

Coordinate 2 of the nMDS analysis separates the $>150 \mu \mathrm{m}$ fraction from the 63 to 150 and $>63 \mu \mathrm{m}$ fractions (Fig. 9a), and the cluster (Bray-Curtis similarity) analysis shows less than $50 \%$ similarity between the two groups (Fig. 9b). However, nMDS coordinate 1 groups all fractions into the same three stations' groups (Fig. 9a) as those previously determined by the CCA analysis based on the $>150 \mu \mathrm{m}$ fraction (Fig. 5). 
(a)

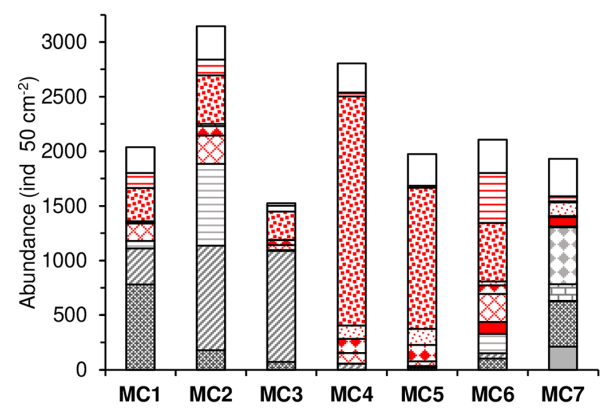

(c)

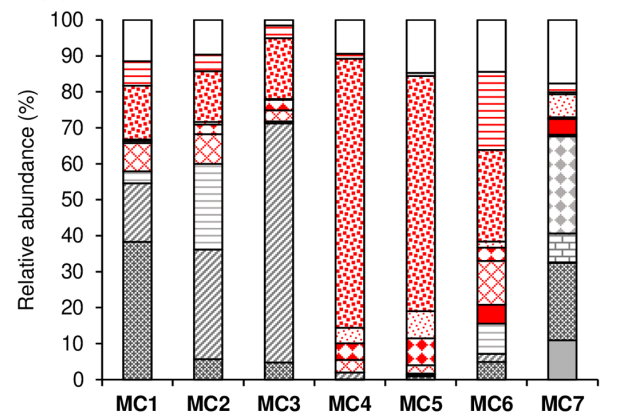

(b)

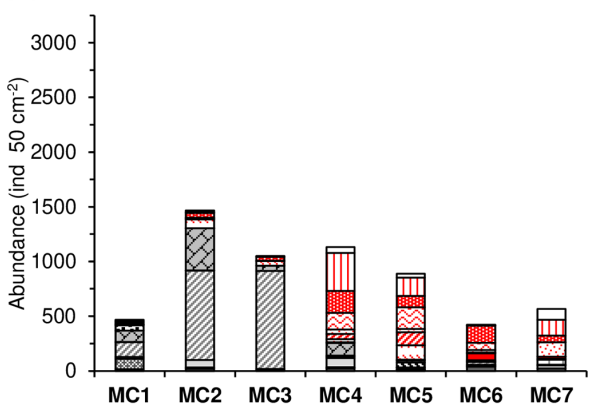

(d)

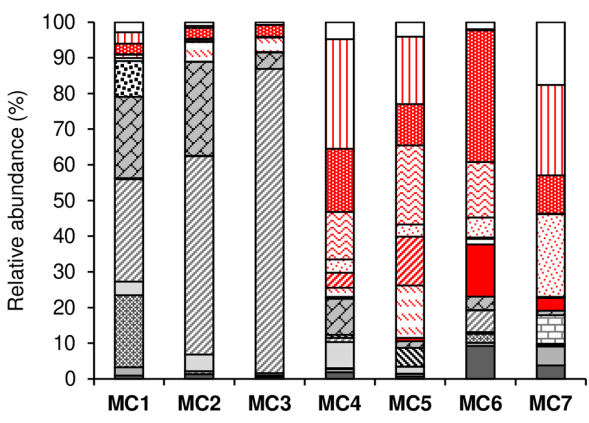

\begin{tabular}{|c|}
\hline$\square$ Cassidulina teretis \\
\hline Elphidium clavatum \\
\hline$\square$ Stainforthia feylingi \\
\hline Ammotium cassis \\
\hline Labrospira crassimargo \\
\hline Reophax fusiformis \\
\hline
\end{tabular}

$\square$ Bucella frigida
$\mathbb{N}$ Cribroelphidium subarcticum
葍Melonis barleeanus
图Triloculina oblonga
图Cuneata arctica
Lagenammina difflugiformis
四Reophax scorpiurus
$\square$ Others

娄 Cassidulina reniforme

$\square$ Elphidium bartletti

Nonionellina labradorica

$\square$ Adercotryma glomeratum

Cribrostomoides $s p$.

图Recurvoides turbinatus

图 Spiroplectammina biformis

$\square$ Others

Figure 7. Total abundances (ind. $50 \mathrm{~cm}^{-2}$ ) and correspondent relative abundances (\%) of the dominant species (>5\% for at least one station) of the $0-1 \mathrm{~cm}$ sediment layer for the $63-150 \mu \mathrm{m}$ fraction $(\mathbf{a}, \mathbf{c})$ and the $>150 \mu \mathrm{m}$ fraction $(\mathbf{b}, \mathbf{d})$. The calcareous species are shown using different grey textures, whereas agglutinated species are shown using different red textures.

(a)

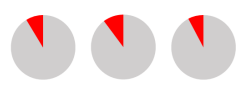

(b)

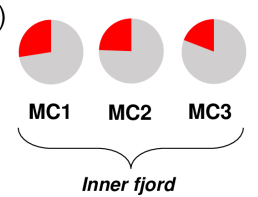

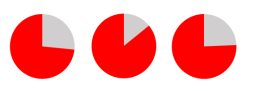

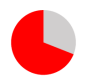

$>150 \mu \mathrm{m}$ fraction

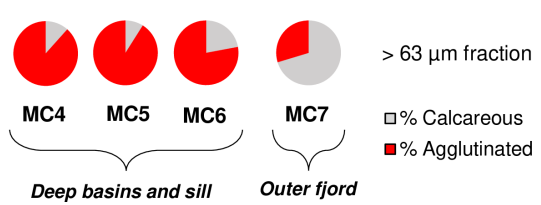

Figure 8. Relative abundances of calcareous foraminifera (in grey) and agglutinated foraminifera (in red) considering the $>150 \mu \mathrm{m}$ size fraction (a) and the $>63 \mu \mathrm{m}$ size fraction (b).

\subsection{Visual characterisation of test dissolution}

At all stations inside the fjord (from MC1 to MC6) most of the calcareous species display different degrees of dissolution, including for small sized specimens. As visualised in Fig. S2 of the Supplement, the species Elphidium clavatum, Elphidium bartletti, Triloculina oblonga and Robertinoides $s p$. show the most severe degree of dissolution, whereas Nonionellina labradorica seems to be less sensitive to dissolution (individuals classified at stage I or II of dissolution). Interestingly, the highest degree of dissolution (stage IV) is exclusively observed in the deep basin and the sill stations. 
(a)

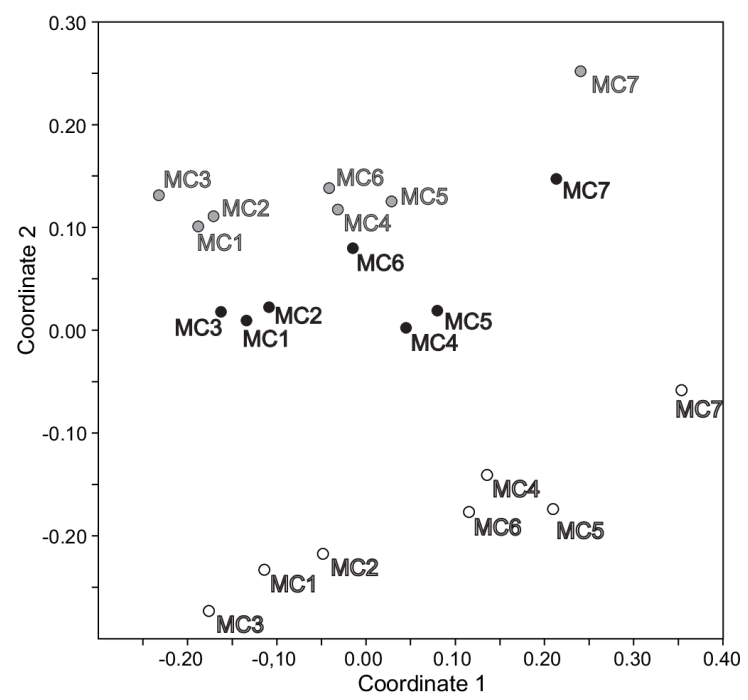

(b)

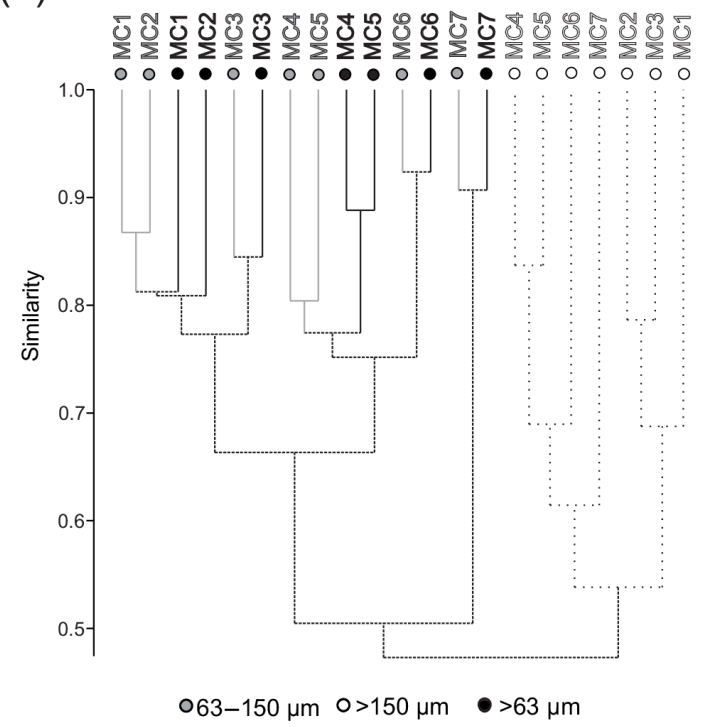

Figure 9. (a) Non-metric multidimensional scaling analysis and (b) cluster analysis (Bray-Curtis similarity measure) considering the densities (ind. $50 \mathrm{~cm}^{-2}$ ) of the major foraminiferal species (relative abundance $>5 \%$ in at least one station in one size fraction) for the $63-150 \mu \mathrm{m}$ fraction, the $>150 \mu \mathrm{m}$ fraction and the $>63 \mu \mathrm{m}$ total fraction.

\section{Discussion}

\subsection{Environmental characteristics of the study area}

According to the topography of the fjord, distribution of the main water masses and physicochemical characteristics of the sediments, we can separate the fjord into three main areas: the inner fjord (i.e. stations MC1 to MC3), the central deep basins (i.e. stations MC4 and MC5) constrained by the sill (i.e. station MC6) and the outer fjord Storfjordrenna (i.e. station MC7) (Fig. 1b).

In July 2016, the inner fjord sea surface water temperatures and salinities (Fig. S3 of the Supplement) are indicative of a mixture between meltwaters and Storfjorden surface water, as previously indicated by Skogseth et al. (2005b). On the contrary, the recorded inner fjord bottom water parameters are not homogeneous (Table 1). In fact, stations $\mathrm{MC} 1$ and $\mathrm{MC} 2$, on the western side of the fjord, are characterised by salinity and temperature within the range of BSW (Skogseth et al., 2005b). The location of these stations in small topographic depressions on the shelf may explain the presence of these cold and salty waters. The shallowest station MC3 (99 m depth), located on the eastern side of the inner fjord, seems influenced by modified Atlantic water (as defined Skogseth et al., 2005b).

The bottom water values of salinity and temperature measured in July 2016 in the deep basins, still allow us to identify the presence of trapped residual BSW a long time after the season of sea ice formation, as previously hypothesised by Skogseth et al. (2005b). The bottom water properties at the sill fall into the range of Arctic water (Skogseth et al., 2005b). In contrast to the inner fjord and the deep basins, the outer fjord water column displays typical values of North Atlantic Water (NAW) from the surface to the bottom (Skogseth et al., 2005b).

The summer melting of tidewater glaciers flowing in Storfjorden produces an important supply of terrigenous materials to the head of the fjord (Winkelmann and Knies, 2005). This sedimentary dynamic results in relatively high sedimentation rates of about $3.6 \pm 0.4 \mathrm{~mm} \mathrm{yr}^{-1}$ recorded in the fjord (stations MC1 to MC6, Table S1), which is lower than in other Svalbard fjords (e.g. Kongsfjorden $5-10 \mathrm{~mm} \mathrm{yr}^{-1}$; Zaborska et al., 2006). Associated with this terrigenous flux, organic matter supply is high in the internal fjord. In contrast, low sedimentation rate $\left(1.3 \pm 0.6 \mathrm{~mm} \mathrm{yr}^{-1}\right.$, Table S1) and low organic matter supply are recorded in the outer fjord. This clearly indicates a lower influence of tidewater glacier inputs in Storfjordrenna (station MC7) compared to the internal fjord (stations MC1 to MC6).

Regarding the organic supply, the high concentrations of organic matter at all our stations, and particularly in the deep basins, confirm the sedimentary organic-rich character of Storfjorden, as previously reported in the literature (Winkelmann and Knies, 2005; Mackensen et al., 2017). The higher $\mathrm{CHO}(\%)$ associated with lower PRT (\%) in the deep basins (station MC4 and MC5) compared to the other stations is indicative of the presence of older and more refractory organic matter (Pusceddu et al., 2000). This could either be related to higher continental supplies of more refractory organic matter, higher heterotrophic consumption, or the presence of longresidence water masses, influenced by BSW and isolated by a strong chemocline during periods of sea ice melting (Rysgaard et al., 2011). In contrast, the higher contents of PRT (\%) and $\mathrm{CPE}$ in the inner fjord (stations $\mathrm{MC} 1$ to $\mathrm{MC} 3$ ) and 
at the sill (MC6) could be the result of a recent (summer) phytoplankton bloom. Compared to the inner fjord, the CPE contents in the Storfjordrenna are much lower (Fig. 2b), indicating a less fresh algal input to the bottom, which is consistent with the greater water depth $(>300 \mathrm{~m})$ at this outer fjord site.

The oxygen profiles and the OPD in particular (Fig. S1a) reflect the quantity of organic matter supplies. Indeed, the organic carbon accumulation depends on its reactivity with available oxygen (Dauwe et al., 2001) and vice versa, the oxygen consumption is proportional to the organic matter mineralisation rate. Except for the outer fjord, all stations (MC1 to MC6) present shallow OPD values $(<10 \mathrm{~mm}$ ) consistent with the high contents of available organic matter (i.e. BPC) (Fig. 2). Organic matter aerobic respiration is also the reason for the rapid $\mathrm{pH}$ decrease in the first millimetre of the sediment column at these stations (Fig. S1b). At the outer fjord, the slower $\mathrm{pH}$ decrease and the higher OPD $(>15 \mathrm{~mm})$ would therefore be attributed to lower BCP content at this station.

\subsection{Distribution of foraminiferal species in response to environmental conditions}

According to the topography and physical characteristics of the fjord, the foraminiferal distribution and the measured environmental parameters also define three biozones: (i) the inner fjord, (ii) the deep basins and sill, and (iii) the outer fjord. The CCA analysis (Fig. 5) shows that the inner fjord fauna are positively correlated to PRT (\%) and negatively correlated to $\mathrm{CHO}(\%)$, meaning that they favourably respond to the availability of fresh and labile organic matter.

Elphidium clavatum dominates the innermost fjord stations, where it preferentially occupies the superficial microhabitats. The high dominance of this species in the inner fjord is consistent with previous findings from other glacierproximal inner Svalbard fjords (Hald and Korsun, 1997; Korsun and Hald, 2000) and Arctic domains (e.g. Iceland; Jennings et al., 2004). Elphidium clavatum is also often described as being able to adapt to harsh environments, such as near tidewater-glacier fronts and riverine estuaries (e.g. Hald and Korsun 1997; Korsun and Hald, 1998; Forwick et al., 2010). The presence of this species therefore suggests quite stressful conditions.

The station MC1, at the fjord head, is additionally characterised by the presence of Cassidulina reniforme. This species tolerates high concentrations of suspended particulate organic matter (Schäfer and Cole, 1986) and prefers cold water environments (Jernas et al., 2018). Korsun and Hald (1998) hypothesised that $C$. reniforme becomes dominant when glacier-driven turbidity is lower and phytoplankton production is higher. According to our findings, fauna at stations MC2 and MC3 potentially reflect a more stressful environment than station MC1. The strong dominance of these two species is also visible in the small size frac- tion, suggesting recent reproductive events, probably in response to fresh organic matter inputs to the seafloor. This hypothesis also matches with the dominance of Nonionellina labradorica in the intermediate microhabitats. In fact, this species is often reported in highly productive areas (Lloyd, 2006) because of its preference for feeding on fresh phytodetritus and on diatoms in particular (Cedhagen, 1991). Korsun and Hald (2000) suggest that this species may start reproducing during spring in glaciomarine environments, possibly following the diatom bloom starting in March under the sea ice (Rysgaard et al., 2011). Therefore, we instead interpret its presence as a response to meltwater discharge and consequent phytoplanktonic bloom. Additionally, Elphidium bartletti that occurs as an accessory species (especially at station MC2) was previously reported in river-affected habitats of the southern Kara Sea, characterised by highly variable environmental conditions (Polyak et al., 2002), further supporting our interpretations.

The CCA analysis (Fig. 6) shows a negative correlation of the deep basins and sill fauna with proteins and a positive correlation with carbohydrates, highlighting a response of the fauna to old (refractory) organic matter. The assemblages in the two deep basin stations (MC4 and MC5) display similar diversities, which are in both cases higher than in the inner fjord. Agglutinated species dominate the topmost centimetre of the sediment, in particular Reophax scorpiurus, Reophax fusiformis, and Recurvoides turbinatus, occasionally accompanied by Labrospira crassimargo and Ammotium cassis. These species are often found in the distal part of other Svalbard fjords (e.g. Hald and Korsun, 1997; Murray and Alve, 2011; Jernas et al., 2018) and widely distributed in areas covered with seasonal sea ice in the Arctic Ocean (e.g. Wollenburg and Kuhnt, 2000; Wollenburg and Mackensen, 1998). They are considered as tolerating low food quality; high sedimentation rates; and a wide range of salinities, temperatures, and organic matter fluxes (Hald and Korsun, 1997; Murray, 2006; Jernas et al., 2018). This capacity for adaptation may explain the abundance of all these agglutinated species in the deep basins where residual BSW (with high $S$, low $T$ and $\mathrm{pH}$ ) and high concentrations of refractory carbohydrates are recorded in the top sediment. At station MC4, $N$. labradorica also lives in a subsurface microhabitat (from 1 down to $3 \mathrm{~cm}$ depth), probably profiting from the phytodetritus supply, as testified by the high CPE contents.

The assemblage composition at the sill (station MC6) is close to those found in the deep basins, except for the dominant presence of Adercotryma glomeratum. The similarities with the deep basin's assemblages are interpreted as the result of intermittent pulses of BSW outflowing the fjord and bypassing the sill during some periods of the year and therefore influencing this station. The opportunist A. glomeratum (e.g. Gooday and Rathburn, 1999; Heinz et al., 2002) has been reported as being positively related to increasing distance from glaciers and from the fjord head (Hald and Korsun, 1997). Its dominance at this station suggests a positive 
relationship with an increase in salinities and temperatures and consequently with Transformed Atlantic Water (TAW) during summer, according to existing literature (e.g. Hald and Korsun, 1997; Jernas et al., 2018). It has therefore been interpreted as the consequence of seasonal influence of Atlantic waters on the sill, when BSW overflow is weakened or absent. In addition to the assemblage composition, the presence of very badly preserved calcareous foraminifera tests and the dominance of agglutinated species in the deep basins plus the sill, strongly suggest that corrosive BSW has a primary control on the benthic ecology in this sector of the fjord.

The outer fjord biozone (station MC7) is characterised by a thicker overlying water column $(>300 \mathrm{~m})$, and higher bottom water salinity and temperature compared to the rest of the studied sites. The presence at this station of agglutinated species shared with the deep basin stations is probably due to the widespread character of these species. However, the clear influence of the NAW at this site is indicated by the presence of typical Atlantic species such as Melonis barleeanus and Globobulimina auriculata. In the North Atlantic Ocean, $M$. barleeanus is described as infaunal and opportunist toward good-quality organic matter (e.g. Caralp et al., 1989; Nardelli et al., 2010). At high latitudes, its presence suggests the influence of relatively warm Atlantic Water (AW) (Caralp, 1989; Polyak et al., 2002; Jennings et al., 2004; Knudsen et al., 2012; Melis et al., 2018). This interpretation is further confirmed by the presence of the deeper dwelling Globobulimina auriculata, presumed to be related to increasing bottom water salinity (Williamson et al., 1984; Jernas et al., 2018) and often associated with buried organic matter (e.g. Alve, 2010).

\subsection{Agglutinated vs. calcareous taxa: the premise of a paleo-proxy of brine formation}

In both size fractions $(63-150$ and $>150 \mu \mathrm{m})$, low agglutinated / calcareous $(\mathrm{A} / \mathrm{C})$ ratios characterise the inner fjord, in contrast to the high values observed at the deep basin and sill stations (Figs. 3b and 8). The exclusive presence of some agglutinated species in the smaller fraction (e.g. Cuneata arctica, Spiroplectammina biformis and Textularia torquata) results in relatively high $\mathrm{A} / \mathrm{C}$ ratios for the $>63 \mu \mathrm{m}$ fraction compared to the $>150 \mu \mathrm{m}$ fraction. It is worth mentioning that in the Storfjordrenna (station MC7) the $\mathrm{A} / \mathrm{C}$ ratio in the $>63 \mu \mathrm{m}$ fraction is lowered by the presence of several small calcareous species (e.g. Stainforthia feylingi, Cassidulina teretis, Alabaminella weddellensis, Cassidulina reniforme) that are not present in the larger fraction (Fig. 8).

Several hypotheses, which are eventually not exclusive, arise to explain the dominance of agglutinated species at the deep basins and sill stations.

i. The influence of organic matter quality. Jernas et al. (2018) suggest that agglutinated species may be more tolerant or less sensitive to the lower quality and/or quantity of food than the calcareous fauna. Following this idea, the dominance of agglutinated species in the deep basins is coherent with the more refractory organic matter (higher CHO \%) measured in July 2016 (Fig. 2). However, the lower percentage of $\mathrm{CHO}$ observed at the sill station MC6 seems to contradict this hypothesis.

ii. The brine-related calcareous test dissolution. Low relative abundances of calcareous taxa found in the sediment in the deep basins could be attributed either to hampered growth, limited reproduction, or test dissolution. Indeed, at the deep basins and sill stations we observe the most severe degree of dissolution on Elphidium clavatum, Elphidium bartletti, Triloculina oblonga and Robertinoides spp in particular (Fig. S2). The most obvious explanation for that is the corrosive effect of brine waters that persist all year round at stations MC4 and MC5 and may impact station MC6 through episodes of overflow from autumn to spring. In the inner fjord stations, these species also present some dissolution, but this is largely less severe (Fig. S2). In our opinion the dissolution at these sites can but either related to early cascading of BSW during winter or to the high seasonal input of meltwater as a factor affecting the preservation of carbonate (Schröder-Adams et al., 1990).

iii. The combined effect of brine and organic matter mineralisation. As an alternative (or in parallel) calcareous test dissolution may result from decaying organic matter. Indeed, test dissolution of E. clavatum species was previously observed in the Adventfjorden (west Svalbard) and was attributed to low $\mathrm{pH}$ in the pore waters of upper sediments due to organic matter decay (Majewski and Zajăğczkowski, 2007), whereas in the BarentsKara shelf this process was associated with sinking of brine (Hald and Steinsund, 1992; Steinsund and Hald, 1994). The coupled effect of corrosive brine and organic matter remineralisation probably simultaneously contributes to the dissolution of the calcareous fauna. It is difficult to decouple the effects of both these factors. However, we observe the most severe degree of dissolution in the deep basins, where organic matter is less available. This lets us conclude that the persistence of brine is the main factor responsible for the dissolution. This conclusion supports some previous paleoceanographical studies from the Arctic, which proposed that the high proportion of agglutinated taxa in sediment cores is dependent on bottom water hydrographical condition (Seidenkrantz et al., 2007) and on corrosive brine production specifically (Rasmussen and Thomsen, 2015).

In light of these arguments, we propose the $\mathrm{A} / \mathrm{C}$ ratio as a proxy for brine persistence and/or overflow in historical sedimentary archives. Rasmussen and Thomsen (2014, 2015) reported an exceptional fossilising potential of agglutinated 
species in this area on records back to $10 \mathrm{ka}$, therefore it is most likely that the ratio is not affected on a timescale of hundreds of years.

\subsection{Insights from the small size fraction}

The additional observation of the small size fraction (63$150 \mu \mathrm{m})$ results in the definition of the same three biozones and similar $\mathrm{A} / \mathrm{C}$ ratios as for the larger fraction (except for the outer fjord station where the ratio changes) (Figs. 8 and 9a). The cluster analysis (Fig. 9b) further shows that the consideration of the $63-150 \mu \mathrm{m}$ fraction increases the percentage of similarity among stations belonging to the same biozone and it increases the dissimilarity between the stations inside the fjord (from MC1 to MC6) and outside the fjord (MC7). Nonetheless, the study of the $63-150 \mu \mathrm{m}$ fraction provides new insights into the benthic foraminiferal ecology of Storfjorden.

At the inner fjord stations MC2 and MC3, the exclusive presence of the calcareous species Stainforthia feylingi and the three agglutinated species Cuneata arctica, Spiroplectammina biformis, and Textularia torquata in the 63-150 $\mu \mathrm{m}$ fraction increases the overall diversity compared to the larger fraction. These four species, with individuals of small size, are typical of Arctic and cold boreal environments and show an opportunistic behaviour in response to a wide range of environmental conditions (e.g. Schäfer and Cole, 1986; Hald and Korsun, 1997; Korsun and Hald, 1998, 2000; Lloyd et al., 2007; Leduc et al., 2002; Pawlowska et al., 2016; Jernas et al., 2018). The presence of numerous juveniles (63$150 \mu \mathrm{m})$ of Elphidium clavatum and Cassidulina reniforme in the inner fjord also confirms recent reproductive events, possibly related to phytoplanktonic bloom and associated fresh organic matter inputs in the benthic system, in agreement with the high percentages of PRT measured in the sediment (Fig. 2).

On the contrary, in the deep basins, the diversity decreases when the small fraction is considered, due to the strong dominance of the agglutinated species S. biformis. In the literature, this is an opportunistic species in glaciomarine habitats, indicative of the presence of cold Arctic waters (Hald and Korsun, 1997; Korsun and Hald, 1998, 2000; Schäfer and Cole, 1986). The high numbers of small individuals found in the deep basins, coupled with the high percentages of $\mathrm{CHO}$, may suggest an eventual positive response of $S$. biformis to refractory organic matter. The relatively high abundances of $T$. torquata at the sill station MC6 suggests high salinity fluctuations (Wollenburg and Kuhnt, 2000), which could be consistent with occasional or seasonal overflow of BSW at this site, further confirming our hypothesis based on the $>150 \mu \mathrm{m}$ assemblages.

In the Storfjordrenna, Cassidulina teretis and $\mathrm{Al}$ abaminella weddellensis are exclusively present in the 63$150 \mu \mathrm{m}$ fraction. These two species, usually associated with AW (Wollenburg and Mackensen, 1998), further give evi- dence of the influence of this water mass in the outer fjord area. The presence of $C$. reniforme at this station exclusively as juveniles is less easy to interpret. Because of its preference for cold waters (e.g. Jernas et al., 2018), its presence could be the result of an occasional influence of Arctic waters on this station.

Taking into consideration the comparison between the 63150 and $>150 \mu \mathrm{m}$ data, the additional information from the small fauna is limited to a slightly more precise estimation of biodiversity and the confirmation of ecological speculations based on the large fauna (e.g. recent blooming events at inner stations). Therefore, regarding the high time-consuming character inherent to the investigation of the $63-150 \mu \mathrm{m}$ fraction, we propose that the small fraction could be neglected in comparable future studies in Storfjorden unless it is studied with the aim of answering some very specific questions.

\section{Conclusions}

Living benthic foraminiferal fauna from the Storfjorden "sea ice factory" were studied in order to determine the response of foraminiferal communities to the major driving factors controlling the sea bottom ecology in this area. The benthic ambient conditions were further connected to brine-enriched shelf waters (BSW) production and persistence and indirectly to first-year sea ice formation. The influence of the BSW persistence on benthic foraminiferal assemblages was identified on the basis of characteristic fauna inhabiting the two deep basins and the sill of the fjord. At these sites, BSW are, respectively, trapped for a long part of the year or overflow during the maximum production period. The assemblages at these stations are dominated by agglutinated taxa, resulting in high agglutinated / calcareous ratio (A/C). The presence of heavily dissolved calcareous tests supports the hypothesis that one of the main factors responsible for this result is the corrosive character of BSW. Additionally, the chemocline related to BSW presence at the bottom could limit the fresh organic matter flux to the seabed and indirectly influence the assemblages.

In light of these results, we propose the application of the $\mathrm{A} / \mathrm{C}$ ratio as a proxy for brine persistence and overflow on historical sedimentary records from Storfjorden, in order to reconstruct past changes in BSW intensity and, by extension, in first-year sea ice production.

Data availability. Raw data are available from the following link: https://doi.org/10.1594/PANGAEA.907687 (Fossile et al., 2019).

Supplement. Tables S1 and S2 and Figs. S1, S2, and S3 can be found in the Supplement. Scanning electron micrographs (plates) of the most relevant species are shown in Figs. S4 and S5 in the Supplement. The supplement related to this article is available online at: https://doi.org/10.5194/bg-17-1933-2020-supplement. 
Author contributions. EF, MM, MPN and $\mathrm{HH}$ wrote the manuscript, which was commented by all co-authors. EM was the cruise leader, and field work was performed by $\mathrm{HH}$ and BL. EF, MPN, MM, HH, AJ, BL and DM collected the data. EF, MPN, MM, HH, AJ, BL and AP analysed and interpreted the data.

Competing interests. The authors declare that they have no conflict of interest.

Acknowledgements. We are grateful to the captain and crew of R/V L'Atalante, which was chartered by IFREMER (French Research Institute for Exploitation of the Sea); Frédéric Vivier (co-chief of the cruise); and all participants who contributed to the success of to the STeP cruise. We particularly thank Bruno Bombled for his technical assistance during the cruise. Original SEM micrographs of foraminiferal species (Figs. S2, S4, S5) were realised by Romain Mallet at SCIAM (Université d'Angers). We fully acknowledge the efficient technical help provided by Sophie Quinchard and Raphäel Hubert-Huard, and we thank Benedicte Ferré for the useful discussions about the oceanography of the study area. We are grateful to Shungo Kawagata and one anonymous reviewer for their constructive comments. This research is part of the $\mathrm{PhD}$ thesis of Eleonora Fossile, which is co-funded by French National Program MOPGA (Make Our Planet Great Again) and the University of Angers.

Financial support. The research was funded by the ABBA (Observatoire des Sciences de l'Univers de Nantes Atlantique), BiSMART (University of Angers) and TANDEM (Région Pays de la Loire) projects.

Review statement. This paper was edited by Hiroshi Kitazato and reviewed by Shungo Kawagata and one anonymous referee.

\section{References}

Aagaard, K., Swift, J. H., and Carmack, E. C.: Thermohaline circulation in the Arctic Mediterranean Seas, J. Geophys. Res., 90, 4833, https://doi.org/10.1029/JC090iC03p04833, 1985.

Alve, E.: Benthic foraminiferal responses to absence of fresh phytodetritus: A two-year experiment, Mar. Micropaleontol., 76, 6775, https://doi.org/10.1016/j.marmicro.2010.05.003, 2010

Anderson, L. G., Falck, E., Jones, E. P., Jutterström, S., and Swift, J. H.: Enhanced uptake of atmospheric $\mathrm{CO}_{2}$ during freezing of seawater: A field study in Storfjorden, Svalbard, J. Geophys. Res., 109, C06004, https://doi.org/10.1029/2003JC002120, 2004.

Appleby, P. G. and Oldfield, F.: The calculation of lead-210 dates assuming a constant rate of supply of unsupported $210 \mathrm{~Pb}$ to the sediment, Catena, 5, 1-8, https://doi.org/10.1016/S03418162(78)80002-2, 1978.

Beszczynska-Moller, A., Fahrbach, E., Schauer, U., and Hansen, E.: Variability in Atlantic water temperature and transport at the en- trance to the Arctic Ocean, 1997-2010, ICES J. Mar. Sci., 69, 852-863, https://doi.org/10.1093/icesjms/fss056, 2012.

Blott, S. J. and Pye, K.: GRADISTAT: a grain size distribution and statistics package for the analysis of unconsolidated sediments, Earth Surf. Proc. Land., 26, 1237-1248, https://doi.org/10.1002/esp.261, 2001.

Caralp, M. H.: Abundance ofBulimina exilis andMelonis barleeanum: Relationship to the quality of marine organic matter, Geo-Mar. Lett., 9, 37-43, https://doi.org/10.1007/BF02262816, 1989.

Cavalieri, D. J. and Martin, S.: The contribution of Alaskan, Siberian, and Canadian coastal polynyas to the cold halocline layer of the Arctic Ocean, J. Geophys. Res., 99, 18343-18362, https://doi.org/10.1029/94JC01169, 1994.

Cedhagen, T.: Retention of chloroplasts and bathymetric distribution in the sublittoral foraminiferan Nonionellina Labradorica, Ophelia, 33, 17-30, https://doi.org/10.1080/00785326.1991.10429739, 1991.

Cottier, F. R., Nilsen, F., Skogseth, R., Tverberg, V., Skarðhamar, J. and Svendsen, H.: Arctic fjords: a review of the oceanographic environment and dominant physical processes, Geol. Soc. Spec. Publ., 344, 35-50, https://doi.org/10.1144/sp344.4, 2010.

Dai, A., Luo, D., Song, M., and Liu, J.: Arctic amplification is caused by sea-ice loss under increasing $\mathrm{CO}_{2}$, Nat. Commun., 10, 1-13, https://doi.org/10.1038/s41467-018-07954-9, 2019.

Danovaro, R.: Methods for the Study of Deep-Sea Sediments, Their Functioning and Biodiversity, CRC Press, Boca Raton, 2009.

Dauwe, B., Middelburg, J. J., and Herman, P. M. J., Effect of oxygen on the degradability of organic matter in subtidal and intertidal sediments of the North Sea area, Mar. Ecol.-Prog. Ser., 215, 1322, https://doi.org/10.3354/meps215013, 2001.

de Jonge, V. N.: Fluctuations in the Organic Carbon to Chlorophyll$a$ Ratios for Estuarine Benthic Diatom Populations, Mar. Ecol.Prog. Ser., 2, 345-353, https://doi.org/10.3354/meps002345, 1980.

Dickson, A. G., Sabine, C. L., and Christian, J. R.: Guide to best practices for ocean $\mathrm{CO}_{2}$ measurements, PICES Special Publication 3, 191 pp., 2007.

Fabiano, M., Danovaro, R., and Fraschetti, S.: A three-year time series of elemental and biochemical composition of organic matter in subtidal sandy sediments of the Ligurian Sea (northwestern Mediterranean), Cont. Shelf Res., 15, 1453-1469, https://doi.org/10.1016/0278-4343(94)00088-5, 1995.

Farmer, D. M. and Freeland, H. J.: The physical oceanography of Fjords, Prog. Oceanogr., 12, 147-220, https://doi.org/10.1016/0079-6611(83)90004-6, 1983.

Fer, I., Skogseth, R., and Haugan, P. M.: Mixing of the Storfjorden overflow (Svalbard Archipelago) inferred from density overturns, J. Geophys. Res., 109, C01005, https://doi.org/10.1029/2003JC001968, 2004.

Forwick, M., Vorren, T. O., Hald, M., Korsun, S., Roh, Y., Vogt, C., and Yoo, K.-C.: Spatial and temporal influence of glaciers and rivers on the sedimentary environment in Sassenfjorden and Tempelfjorden, Spitsbergen, Geol. Soc. Spec. Publ., 344, 163193, https://doi.org/10.1144/SP344.13, 2010.

Fossile, E., Nardelli, M. P., and Mojtahid, M.: STEP2016 living foraminifera in surface sediments of a N-S transect in the Storfjorden, PANGAEA, https://doi.org/10.1594/PANGAEA.907687, 2019. 
Geyer, F., Fer, I., and Eldevik, T.: Dense overflow from an Arctic fjord: Mean seasonal cycle, variability and wind influence, Cont. Shelf Res., 29, 2110-2121, https://doi.org/10.1016/j.csr.2009.08.003, 2009.

Gleitz, M., Rutgers v.d. Loeff, M., Thomas, D. N., Dieckmann, G. S., and Millero, F. J.: Comparison of summer and winter inorganic carbon, oxygen and nutrient concentrations in Antarctic sea ice brine, Mar. Chem., 51, 81-91, https://doi.org/10.1016/0304-4203(95)00053-T, 1995.

Gonzales, M. V., De Almeida, F. K., Costa, K. B., Santarosa, A. C. A., Camillo, E., De Quadros, J. P., and Toledo, F. A. L.: Help Index: Hoeglundina Elegans Preservation Index for Marine Sediments in the Western South Atlantic, J. Foramin. Res., 47, 56-69, https://doi.org/10.2113/gsjfr.47.1.56, 2017.

Gooday, A. J. and Rathburn, A. E.: Temporal variability in living deep-sea benthic foraminifera: a review, Earth Sci. Rev., 46, 187212, https://doi.org/10.1016/S0012-8252(99)00010-0, 1999.

Grasshoff, K., Ehrhardt, M., and Kremling, K.: Methods of seawater analysis, second revised and extended edition, Academia press, London, New York, 1983.

Haarpaintner, J., Gascard, J., and Haugan, P. M.: Ice production and brine formation in Storfjorden, Svalbard, J. Geophys. Res.-Oceans, 106, 14001-14013, https://doi.org/10.1029/1999JC000133, 2001a.

Haarpaintner, J., Haugan, P. M., and Gascard, J. C.: Interannual variability of the Storfjorden (Svalbard) ice cover and ice production observed by ERS-2 SAR, Ann. Glaciol., 33, 430-436, 2001b.

Haarpaintner, J., O’Downer, J., Gascard, J. C., Haugan, P. M., Schauer, U. and Øterhus, S.: Seasonal transformation of water masses, circulation and brine formation observed in Storfjorden, Svalbard, Ann. Glaciol., 33, 437-443, https://doi.org/10.3189/172756401781818635, 2001c.

Hald, M. and Korsun, S.: Distribution of modern benthic foraminifera from fjords of Svalbard, European Arctic, J. Foramin. Res., 27, 101-122, https://doi.org/10.2113/gsjfr.27.2.101, 1997.

Hald, M. and Steinsund, P. I.: Distribution of surface sediment benthic foraminifera in the southwestern Barents Sea, J. Foramin. Res., 22, 347-362, https://doi.org/10.2113/gsjfr.22.4.347, 1992.

Hammer, Ø., Harper, D., and Ryan, P. D.: PAST: Palaeontological statistics software package for education and data analysis, Palaeontol. Electron., 4, 1-9, 2001.

Hansen, A. and Knudsen, K. L.: Recent foraminiferal distribution in Freemansundet and Early Holocene stratigraphy on Edgeøya, Svalbard, Polar Res., 14, 215-238, https://doi.org/10.3402/polar.v14i2.6664, 1995.

Heinz, P., Hemleben, C., and Kitazato, H.: Time-response of cultured deep-sea benthic foraminifera to different algal diets, Deep-Sea Res. Pt. I, 49, 517-537, https://doi.org/10.1016/S09670637(01)00070-X, 2002.

Holland, M. M. and Bitz, C. M.: Polar amplification of climate change in coupled models, Clim. Dynam., 21, 221-232, https://doi.org/10.1007/s00382-003-0332-6, 2003.

Holliday, N. P., Hughes, S. L., Bacon, S., Beszczynska-Möller, A., Hansen, B., Lavín, A., Loeng, H., Mork, K. A., Østerhus, S., Sherwin, T., and Walczowski, W.: Reversal of the 1960 s to 1990 s freshening trend in the northeast North
Atlantic and Nordic Seas, Geophys. Res. Lett., 35, 1-5, https://doi.org/10.1029/2007GL032675, 2008.

Horner, R. and Schrader, G. C.: Relative Contributions of Ice Algae, Phytoplankton, and Benthic Microalgae to Primary Production in Nearshore Regions of the Beaufort Sea, Arctic, 35, 485-503, 1982.

IPCC: Climate Change 2013: The Physical Science Basis. Contribution of Working Group I Contribution to the Fifth Assessment Report of the Intergovernmental Panel on Climate Change, edited by: Stocker, T. F., Qin, D. Plattner, G.K., Tignor, M., Allen, S. K., Boschung, J., Nauels, A., Xia, Y., Bex, V., and Midgley, P. M., Cambridge Univ. Press, Cambridge, UK, New York, NY, USA, 1535 pp., https://doi.org/10.1017/CBO9781107415324, 2013.

Ivanova, E. V., Ovsepyan, E. A., Risebrobakken, B., and Vetrov, A. A.: Downcore distribution of living calcareous foraminifera and stable isotopes in the Western Barents Sea, J. Foramin. Res., 38, 337-356, https://doi.org/10.2113/gsjfr.38.4.337, 2008.

Jardon, F. P., Vivier, F., Bouruet-Aubertot, P., Lourenço, A., Cuypers, Y., and Willmes, S.: Ice production in Storfjorden (Svalbard) estimated from a model based on AMSR-E observations: Impact on water mass properties, J. Geophys. Res.-Oceans, 119, 377-393, https://doi.org/10.1002/2013JC009322, 2014.

Jennings, A. E., Weiner, N. J., Helgadottir, G., and Andrews, J. T.: Modern Foraminiferal Faunas of the Southwestern To Northern Iceland Shelf: Oceanographic and Environmental Controls, J. Foramin. Res., 34, 180-207, https://doi.org/10.2113/34.3.180, 2004.

Jernas, P., Klitgaard-Kristensen, D., Husum, K., Koç, N., Tverberg, V., Loubere, P., Prins, M., Dijkstra, N., and Gluchowska, M.: Annual changes in Arctic fjord environment and modern benthic foraminiferal fauna: Evidence from Kongsfjorden, Svalbard, Global Planet. Change, 163, 119-140, https://doi.org/10.1016/j.gloplacha.2017.11.013, 2018.

Jorissen, F. J., de Stigter, H. C., and Widmark, J. G. V: A conceptual model explaining benthic foraminiferal microhabitats, Mar. Micropaleontol., 26, 3-15, https://doi.org/10.1016/03778398(95)00047-X, 1995.

Kinnard, C., Zdanowicz, C. M., Fisher, D. A., Isaksson, E., de Vernal, A., and Thompson, L. G.: Reconstructed changes in Arctic sea ice over the past 1450 years, Nature, 479, 509-512, https://doi.org/10.1038/nature10581, 2011.

Kitazato, H., Shirayama, Y., Nakatsuka, T., Fujiwara, S., Shimanaga, M., Kato, Y., Okada, Y., Kanda, J., Yamaoka, A., Masuzawa, T., and Suzuki, K.: Seasonal phytodetritus deposition and responses of bathyal benthic foraminiferal populations in Sagami Bay, Japan: preliminary results from "Project Sagami 1996-1999", Mar. Micropaleontol., 40, 135149, https://doi.org/10.1016/S0377-8398(00)00036-0, 2000.

Knudsen, K. L., Eiríksson, J., and Bartels-Jónsdóttir, H. B.: Oceanographic changes through the last millennium off North Iceland: Temperature and salinity reconstructions based on foraminifera and stable isotopes, Mar. Micropaleontol., 84-85, 54-73, https://doi.org/10.1016/j.marmicro.2011.11.002, 2012.

Korsun, S. and Hald, M.: Modern benthic foraminifera off Novaya Zemlya tidewater glaciers, Russian Arctic, Arct. Antarct. Alp. Res., 30, 61-77, https://doi.org/10.2307/1551746, 1998. 
Korsun, S. and Hald, M.: Seasonal dynamics of Benthic Foraminifera in a Glacially Fed Fjord of Svalbard, European Arctic, J. Foramin. Res., 30, 251-271, https://doi.org/10.2113/0300251, 2000.

Korsun, S. A., Pogodina, I. A., Forman, S. L., and Lubinski, D. J.: Recent foraminifera in glaciomarine sediments from three arctic fjords of Novaja Zemlja and Svalbard, Polar Res., 14, 15-32, https://doi.org/10.3402/polar.v14i1.6648, 1995.

Labe, Z., Magnusdottir, G., and Stern, H.: Variability of Arctic sea ice thickness using PIOMAS and the CESM large ensemble, J. Climate, 31, 3233-3247, https://doi.org/10.1175/JCLI-D17-0436.1, 2018.

Łącka, M. and Zajączkowski, M.: Does the recent pool of benthic foraminiferal tests in fjordic surface sediments reflect interannual environmental changes? The resolution limit of the foraminiferal record, Ann. Soc. Geol. Pol., 86, 59-71, https://doi.org/10.14241/asgp.2015.019, 2016.

Leduc, J., Bilodeau, G., De Vernal, A., and Mucci, A.: Distribution of benthic foraminiferal populations in surface sediments of the Saguenay Fjord, before and after the 1996 flood, Palaeogeogr. Palaeoclimatol. Palaeoecol., 180, 207-223, https://doi.org/10.1016/S0031-0182(01)00429-1, 2002.

Lloyd, J., Kuijpers, A., Long, A., Moros, M., and Park, L. A.: Foraminiferal reconstruction of mid- to lateHolocene ocean circulation and climate variability in Disko Bugt, West Greenland, Holocene, 8, 1079-1091, https://doi.org/10.1177/0959683607082548, 2007.

Lloyd, J. M.: Modern Distribution of Benthic Foraminifera From Disko Bugt, West Greenland, J. Foramin. Res., 36, 315-331, https://doi.org/10.2113/gsjfr.36.4.315, 2006.

Loeng, H.: Features of the physical oceanographic conditions of the Barents Sea, Polar Res., 10, 5-18, https://doi.org/10.3402/polar.v10i1.6723, 1991.

Lorenzen, C. J. and Jeffrey, S. W.: Determination of chlorophyll in seawater, Unesco Tech. Pap. Mar. Sci., 35, 1-20, 1980.

Lydersen, C., Assmy, P., Falk-Petersen, S., Kohler, J., Kovacs, K. M., Reigstad, M., Steen, H., Strøm, H., Sundfjord, A., Varpe, Ø., Walczowski, W., Weslawski, J. M., and Zajączkowski, M.: The importance of tidewater glaciers for marine mammals and seabirds in Svalbard, Norway, J. Marine Syst., 129, 452-471, https://doi.org/10.1016/j.jmarsys.2013.09.006, 2014.

Mackensen, A., Schmiedl, G., Thiele, J., and Damm, E.: Microhabitat preferences of live benthic foraminifera and stable carbon isotopes off SW Svalbard in the presence of widespread methane seepage, Mar. Micropaleontol., 132, 1-17, https://doi.org/10.1016/j.marmicro.2017.04.004, 2017.

Majewski, W. and Zajączkowski, M.: Benthic Foraminifera in Adventfjorden, Svalbard: Last 50 Years of Local Hydrographic Changes, J. Foramin. Res., 37, 107-124, https://doi.org/10.2113/gsjfr.37.2.107, 2007.

McPhee, M. G., Skogseth, R., Nilsen, F., and Smedsrud, L. H.: Creation and tidal advection of a cold salinity front in Storfjorden: 2. Supercooling induced by turbulent mixing of cold water, J. Geophys. Res.-Oceans, 118, 3737-3751, https://doi.org/10.1002/jgrc.20261, 2013.

Melis, R., Carbonara, K., Villa, G., Morigi, C., Bárcena, M. A., Giorgetti, G., Caburlotto, A., Rebesco, M., and Lucchi, R. G.: A new multi-proxy investigation of Late Quaternary palaeoen- vironments along the north-western Barents Sea (Storfjorden Trough Mouth Fan), J. Quaternary Sci., 33, 662-676, https://doi.org/10.1002/jqs.3043, 2018.

Misund, O. A., Heggland, K., Skogseth, R., Falck, E., Gjøsæter, H., Sundet, J., Watne, J., and Lønne, O. J.: Norwegian fisheries in the Svalbard zone since 1980. Regulations, profitability and warming waters affect landings, Polar Sci., 10, 312-322, https://doi.org/10.1016/j.polar.2016.02.001, 2016.

Murray, J. W.: Ecology and Application of Benthic Foraminifera, Cambridge University Press, Cambridge, New York, https://doi.org/10.1017/CBO9780511535529, 2006.

Murray, J. W. and Alve, E.: The distribution of agglutinated foraminifera in NW European seas: Baseline data for the interpretation of fossil assemblages, Palaeontol. Electron., 14, 1-41, 2011.

Nardelli, M., Jorissen, F., Pusceddu, A., Morigi, C., Dell'Anno, A., Danovaro, R., De Stigter, H. C., and Negri, A.: Living benthic foraminiferal assemblages along a latitudinal transect at $1000 \mathrm{~m}$ depth off the Portuguese margin, Micropaleontology, 56, 323344, 2010.

Nicolle, M., Debret, M., Massei, N., Colin, C., deVernal, A., Divine, D., Werner, J. P., Hormes, A., Korhola, A., and Linderholm, H. W.: Climate variability in the subarctic area for the last 2 millennia, Clim. Past, 14, 101-116, https://doi.org/10.5194/cp14-101-2018, 2018.

Nielsen, T. and Rasmussen, T. L.: Reconstruction of ice sheet retreat after the Last Glacial maximum in Storfjorden, southern Svalbard, Mar. Geol., 402, 228-243, https://doi.org/10.1016/j.margeo.2017.12.003, 2018

Ohga, T. and Kitazato, H.: Seasonal changes in bathyal foraminiferal populations in response to the flux of organic matter (Sagami Bay, Japan), Terra Nova, 9, 33-37, https://doi.org/10.1046/j.1365-3121.1997.d01-6.x, 1997.

Omar, A., Johannessen, T., Bellerby, R. G. J., Olsen, A., Anderson, L. G., and Kivimae, C.: Sea-Ice and Brine Formation in Storfjorden: Implications for the Arctic Wintertime Air-Sea $\mathrm{CO}_{2}$ Flux, in: The Nordic Seas: An Integrated Perspective, edited by: Drange, H., Dokken, T., Furevik, T., Gerdes, R., and Berger, W., Geophysical Monograph 158, American Geophysical Union, Washington, DC, 117-187, https://doi.org/10.1029/158GM12, 2005.

Pawłowska, J., Zajączkowski, M., Łącka, M., Lejzerowicz, F., Esling, P., and Pawlowski, J.: Palaeoceanographic changes in Hornsund Fjord (Spitsbergen, Svalbard) over the last millennium: new insights from ancient DNA, Clim. Past, 12, 1459-1472, https://doi.org/10.5194/cp-12-1459-2016, 2016.

Pedrosa, M. T., Camerlenghi, A., De Mol, B., Urgeles, R., Rebesco, M., and Lucchi, R. G.: Seabed morphology and shallow sedimentary structure of the Storfjorden and Kveithola troughmouth fans (north west Barents Sea), Mar. Geol., 286, 65-81, https://doi.org/10.1016/j.margeo.2011.05.009, 2011.

Peings, Y.: The atmospheric response to sea-ice loss, Nat. Clim. Chang., 8, 664-665, https://doi.org/10.1038/s41558-018-0243-5, 2018.

Perovich, D. K. and Richter-Menge, J. A.: Loss of Sea Ice in the Arctic, Annu. Rev. Mar. Sci., 1, 417-441, https://doi.org/10.1146/annurev.marine.010908.163805, 2009. 
Piechura, J. and Walczowski, W.: Warming of the West Spitsbergen Current and sea ice north of Svalbard, Oceanologia, 51, 147-164, https://doi.org/10.5697/oc.51-2.147, 2009.

Pierrot, D., Lewis, E., and Wallace, D. W. R.: MS Excel program developed for $\mathrm{CO}_{2}$ system calculations, ORNL/CDIAC-105a, Carbon Dioxide Information Analysis Center, Oak Ridge National Laboratory, US Department of Energy, Oak Ridge, Tennessee, 2006.

Plante-Cuny, M. R.: Evaluation par spectrophotométrie des teneurs en chlorophylle- $a$ fonctionnelle et en phéopigments des substrats meubles marins, Doc. Sci. la Mission l'O.R.S.T.O.M. à Nosy-Bé, 45, 76, 1974.

Polyak, L., Korsun, S., Febo, L. A., Stanovoy, V., Khusid, T., Hald, M., Paulsen, B. E., and Lubinski, D. J.: Benthic foraminiferal assemblages from the Southern Kara Sea, a riverinfluenced Arctic marine environment, J. Foramin. Res., 32, 252273, 2002.

Polyakov, I. V., Walsh, J. E., and Kwok, R.: Recent changes of Arctic multiyear sea ice coverage and the likely causes, B. Am. Meteorol. Soc., 93, 145-151, https://doi.org/10.1175/BAMS-D-11$00070.1,2012$.

Pusceddu, A., Dell'Anno, A., and Fabiano, M.: Organic matter composition in coastal sediments at Terra Nova Bay (Ross Sea) during summer 1995, Polar Biol., 23, 288-293, https://doi.org/10.1007/s003000050446, 2000.

Pusceddu, A., Dell'Anno, A., Danovaro, R., Manini, E., Sarà, G., and Fabiano, M.: Enzymatically hydrolyzable protein and carbohydrate sedimentary pools as indicators of the trophic state of detritus sink systems: A case study in a mediterranean coastal lagoon, Estuaries, 26, 641-650, https://doi.org/10.1007/BF02711976, 2003.

Pusceddu, A., Dell'Anno, A., Fabiano, M., and Danovaro, R.: Quantity and bioavailability of sediment organic matter as signatures of benthic trophic status, Mar. Ecol.-Prog. Ser., 375, 41-52, https://doi.org/10.3354/meps07735, 2009.

Pusceddu, A., Bianchelli, S., Canals, M., Sanchez-Vidal, A., Durrieu De Madron, X., Heussner, S., Lykousis, V., de Stigter, H., Trincardi, F., and Danovaro, R.: Organic matter in sediments of canyons and open slopes of the Portuguese, Catalan, Southern Adriatic and Cretan Sea margins, Deep-Sea Res. Pt. I, 57, 441457, https://doi.org/10.1016/j.dsr.2009.11.008, 2010.

Quadfasel, D., Rudels, B., and Kurz, K.: Outflow of dense water from a Svalbard fjord into the Fram Strait, Deep-Sea Res. Pt. I, 35, 1143-1150, https://doi.org/10.1016/0198-0149(88)90006-4, 1988.

Rasmussen, T. L. and Thomsen, E.: Stable isotope signals from brines in the Barents Sea: Implications for brine formation during the last glaciation, Geology, 37, 903-906, https://doi.org/10.1130/G25543A.1, 2009.

Rasmussen, T. L. and Thomsen, E.: Brine formation in relation to climate changes and ice retreat during the last 15000 years in Storfjorden, Svalbard, 76-78 ${ }^{\circ}$ N, Paleoceanography, 29, 911929, https://doi.org/10.1002/2014PA002643, 2014.

Rasmussen, T. L. and Thomsen, E.: Palaeoceanographic development in Storfjorden, Svalbard, during the deglaciation and Holocene: Evidence from benthic foraminiferal records, Boreas, 44, 24-44, https://doi.org/10.1111/bor.12098, 2015.
Revsbech, N. P.: An oxygen microsensor with a guard cathode, Limnol. Oceanogr., 34, 474-478, https://doi.org/10.4319/lo.1989.34.2.0474, 1989.

Rudels, B. and Quadfasel, D.: Convection and deep water formation in the Arctic Ocean-Greenland Sea System, J. Marine Syst., 2, 435-450, https://doi.org/10.1016/0924-7963(91)90045-V, 1991.

Rysgaard, S., Bendtsen, J., Delille, B., Dieckmann, G. S., Glud, R. N., Kennedy, H., Mortensen, J., Papadimitriou, S., Thomas, D. N., and Tison, J. L.: Sea ice contribution to the airsea $\mathrm{CO}_{2}$ exchange in the Arctic and Southern Oceans, Tellus B, 63, 823-830, https://doi.org/10.1111/j.1600-0889.2011.00571.x, 2011.

Rumohr, J., Blaume, F., Erlenkeuser, H., Fohrmann, H., Hollender, F.-J., Mienert, J., and Schäfer-Neth, C.: Records and processes of near-bottom sediment transport along the NorwegianGreenland Sea margins during Holocene and late Weichselian (Termination I) times, in: The Northern North Atlantic: A Changing Environment, edited by: Schäfer, P., Ritzau, W., Schlüter, M., and Thiede, J., Springer, Berlin, Heidelberg, 155178, https://doi.org/10.1007/978-3-642-56876-3_10, 2001.

Sabbatini, A., Morigi, C., Negri, A., and Gooday, A. J.: Distribution and biodiversity of stained monothalamous foraminifera from Tempelfjord, Svalbard, J. Foramin. Res., 37, 93-106, https://doi.org/10.2113/gsjfr.37.2.93, 2007.

Sanchez-Cabeza, J. A. and Ruiz-Fernández, A. C.: ${ }^{210} \mathrm{~Pb}$ sediment radiochronology: An integrated formulation and classification of dating models, Geochim. Cosmochim. Ac., 82, 183-200, https://doi.org/10.1016/j.gca.2010.12.024, 2012.

Schäfer, C. T. and Cole, F. E.: Reconnaissance Survey of Benthonic Foraminifera from Baffin Island Fiord Environments, Arctic, 39, 232-239, 1986.

Schauer, U.: The release of brine-enriched shelf water from Storfjord into the Norwegian Sea, J. Geophys. Res., 100, 1601516028, https://doi.org/10.1029/95JC01184, 1995.

Schönfeld, J., Alve, E., Geslin, E., Jorissen, F., Korsun, S., Spezzaferri, S., Abramovich, S., Almogi-Labin, A., du Chatelet, E. A., Barras, C., Bergamin, L., Bicchi, E., Bouchet, V., Cearreta, A., Di Bella, L., Dijkstra, N., Disaro, S. T., Ferraro, L., Frontalini, F., Gennari, G., Golikova, E., Haynert, K., Hess, S., Husum, K., Martins, V., McGann, M., Oron, S., Romano, E., Sousa, S. M., and Tsujimoto, A.: The FOBIMO (FOraminiferal BIo-MOnitoring) initiative Towards a standardised protocol for soft-bottom benthic foraminiferal monitoring studies, Mar. Micropaleontol., 94-95, 1-13, https://doi.org/10.1016/j.marmicro.2012.06.001, 2012.

Schröder-Adams, C. J., Cole, F. E., Medioli, F. S., Mudie, P. J., Scott, D. B., and Dobbin, L.: Recent Arctic shelf foraminifera: seasonally ice covered vs. perennially ice covered areas, J. Foramin. Res., 20, 8-36, https://doi.org/10.2113/gsjfr.20.1.8, 1990.

Seidenkrantz, M. S., Aagaard-Sørensen, S., Sulsbrück, H., Kuijpers, A., Jensen, K. G., and Kunzendorf, H.: Hydrography and climate of the last 4400 years in a SW Greenland fjord: Implications for Labrador Sea palaeoceanography, Holocene, 17, 387401, https://doi.org/10.1177/0959683607075840, 2007.

Skogseth, R., Haugan, P. M., and Haarpaintner, J.: Ice and brine production in Storfjorden from four winters of satellite and in situ observations and modeling, J. Geophys. Res.-Oceans, 109, 1-15, https://doi.org/10.1029/2004JC002384, 2004. 
Skogseth, R., Fer, I., and Haugan, P. M.: Dense-water production and overflow from an arctic coastal polynya in Storfjorden, Geophys. Monogr. Ser., 158, 73-88, https://doi.org/10.1029/158GM07, 2005a.

Skogseth, R., Haugan, P. M., and Jakobsson, M.: Watermass transformations in Storfjorden, Cont. Shelf Res., 25, 667-695, https://doi.org/10.1016/j.csr.2004.10.005, 2005b.

Skogseth, R., Smedsrud, L. H., Nilsen, F., and Fer, I.: Observations of hydrography and downflow of brine-enriched shelf water in the Storfjorden polynya, Svalbard, J. Geophys. Res.-Oceans, 113, 1-13, https://doi.org/10.1029/2007JC004452, 2008.

Smedsrud, L. H., Budgell, W. P., Jenkins, A. D., and Ådlandsvik, B.: Fine-scale sea-ice modelling of the Storfjorden polynya, Svalbard, Ann. Glaciol., 44, 73-79, https://doi.org/10.3189/172756406781811295, 2006.

Smethie, W. M., Ostlundt, H. G., and Loosli, H. H.: Ventilation of the deep Greenland and Norwegian seas: evidence from krypton85, tritium, carbon-14 and argon-39, Deep-Sea Res., 33, 675703, 1986.

Steinsund, P. I. and Hald, M.: Recent calcium carbonate dissolution in the Barents Sea: Paleoceanographic applications, Mar. Geol., 117, 303-316, https://doi.org/10.1016/0025-3227(94)90022-1, 1994.

Tamura, T. and Ohshima, K. I.: Mapping of sea ice production in the Arctic coastal polynyas, J. Geophys. Res.-Oceans, 116, 120, https://doi.org/10.1029/2010JC006586, 2011.

Tselepides, A., Polychronaki, T., Marrale, D., Akoumianaki, I., Dell'Anno, A., Pusceddu, A., and Danovaro, R.: Organic matter composition of the continental shelf and bathyal sediments of the Cretan Sea (NE Mediterranean), Prog. Oceanogr., 46, 311-344, https://doi.org/10.1016/S0079-6611(00)00024-0, 2000.

van Oevelen, D., Soetaert, K., Garcia, R., de Stigter, H. C., Cunha, M. R., Pusceddu, A., and Danovaro, R.: Canyon conditions impact carbon flows in food webs of three sections of the Nazaré canyon, Deep-Sea Res. Pt. II, 58, 2461-2476, https://doi.org/10.1016/j.dsr2.2011.04.009, 2011.
Wekerle, C., Wang, Q., Danilov, S., Schourup-Kristensen, V., von Appen, W.-J., and Jung, T.: Atlantic Water in the Nordic Seas: Locally eddy-permitting ocean simulation in a global setup, J. Geophys. Res.-Oceans, 122, 914-940, https://doi.org/10.1002/2016JC012121, 2016.

Williamson, M. A., Keen, C. E., and Mudie, P. J.: Foraminiferal distribution on the continental margin off Nova Scotia, Mar. Micropaleontol., 9, 219-239, 1984.

Winkelmann, D. and Knies, J.: Recent distribution and accumulation of organic carbon on the continental margin west off Spitsbergen, Geochem. Geophys. Geosy., 6, Q09012, https://doi.org/10.1029/2005GC000916, 2005.

Wollenburg, J. E. and Kuhnt, W.: The response of benthic foraminifers to carbon flux and primary production in the Arctic Ocean, Mar. Micropaleontol., 40, 189-231, https://doi.org/10.1016/S0377-8398(00)00039-6, 2000.

Wollenburg, J. E. and Mackensen, A.: Living benthic foraminifers from the central Arctic Ocean: Faunal composition, standing stock and diversity, Mar. Micropaleontol., 34, 153-185, https://doi.org/10.1016/S0377-8398(98)00007-3, 1998.

Zaborska, A., Pempkowiak, J., and Papucci, C.: Some Sediment Characteristics and Sedimentation Rates in an Arctic Fjord (Kongsfjorden, Svalbard), Annu. Environ. Prot., 8, 79-96, 2006.

Zajączkowski, M., Szczuciński, W., and Bojanowski, R.: Recent changes in sediment accumulation rates in Adventfjorden, Svalbard, Oceanologia, 46, 217-231, 2004.

Zajączkowski, M., Szczuciński, W., Plessen, B., and Jernas, P.: Benthic foraminifera in Hornsund, Svalbard: Implications for paleoenvironmental reconstructions, Pol. Polar Res., 31, 349-375, 2010 . 